[Vicino Oriente XXIV (2020), pp. 27-55]

\title{
AN IRON AGE II TOMB WITH PHOENICIAN ITEMS AT KHIRBET BIR EL-KHARAYIB, CENTRAL PALESTINE
}

\author{
Awni Shawamra - Ministry of Tourism and Antiquities of Palestine \\ Federico Cappella* - Sapienza University of Rome
}

In 2017, during a salvage excavation carried out by the Department of Antiquities and Cultural Heritage of Palestine, an Iron Age shaft tomb close to the site of Khirbet Bir el-Kharayib in Central Palestine came to light. The funerary equipment of the tomb goes within the Iron Age IIA pottery tradition. Vessels of this period primarily consist of Red Slip Ware bowls and juglets, Black Slip Ware juglets, Simple Ware jars, jugs and juglets, and Cooking Ware pots. A Bichrome Ware jug, a bronze bowl and a zoomorphic figurine complete the funerary set.

Keywords: tomb; grave goods; Palestine; Salfit; Iron Age II

\section{INTRODUCTION}

Khirbet Bir el-Kharayib arises on a low plateau in central Palestine, $640 \mathrm{~m}$ a.s.l., and is located $3 \mathrm{~km}$ east of the city of Salfit in between the Districts of Nablus and Ramallah (fig. 1). ${ }^{1}$ Some surveys carried on in this area by the members of MOTA in 2017 and before, between 1980 and 1987, by I. Finkelstein, Z. Lederman and S. Bunimovitz attested to the human presence in this area from the Bronze Age onwards. Later occupation was documented from Iron Age until the Islamic Period, with an intensification during the Iron Age II. ${ }^{2}$

As described by Finkelstein and Lederman, the site consists of ruins covered by heaps of stones and some terraces built on the ancient walls.

The tomb, discovered about $200 \mathrm{~m}$ south to the site, is surrounded by many others shaft tombs, caves and wine presses but the cemetery was unfortunately looted in the past and, additionally, the area between Khirbet Bir el-Kharayib and the cemetery is still used today as a landfill by the local residents with significant impact on the archeological remains. The Police of Tourism and Antiquities contributed to stop the pillaging which hardly effected

* I wish to thank Prof. Lorenzo Nigro, Director of Sapienza University Archaeological Expedition to Palestine \& Jordan, and the Ministry of Tourism and Antiquities (MOTA), Mr. Awni Shawamra and the Department of Antiquities and Cultural Heritage $(\mathrm{DACH})$ for giving me the opportunity to study the finds presented in this article.

1 Palmer suggested that the name "Salfit" was derived it from the plowed sown field due to the fertile soil all around the Salfit area (Palmer 1881, 241), while local people interpret the meaning Salfit as "basket of grapes". During early Islamic period the village of Salfit flourished and continued to exist through Crusader period. In the $12^{\text {th }}$ and $13^{\text {th }}$ centuries AD the town was inhabited by Muslims (Ellenblum 2003, 263). In 1517 Palestine was incorporated into the Ottoman Empire. In 1596 the village, with a population of 118 households, appeared in Ottoman tax registers under the name of Salfit al-Basal and it was in the Nahiya "Subdistrict" of Jabal Qubal, part of the Liwa "District" of Nablus. Its residents paid taxes on wheat, barley, summer crops, olives, goats and beehives (Hütteroth - Abdulfattah 1977, 132). In 1882 Salfit was described in SWP as a large village located on a high ground with olive groves all around and a pool to the east. By 1916 Salfit was one of the two largest villages in the District of Nablus that produced olive oil (Doumani 1995, 150).

2 Finkelstein - Lederman eds. 1997, 473, 597-598.

ISSN 0393-0300

e-ISSN 2532-5159

Rivista Open Access 
the tomb, before it was dug during a salvage excavation in 2017 by A. Shawamra with the contribution of M. Musa, A. Barakat, M.A. Zrieq and with the photographic support of M. Bargouthi. ${ }^{3}$

\section{DESCRIPTION OF THE TOMB}

The tomb discovered at Khirbet Bir el-Kharayib is a shaft tomb almost circular in shape hewn in the very soft limestone bedrock (figs. 2-3). The diameter of the shaft measures $1.20 \mathrm{~m}$ while the single chamber of the tomb measures almost 3 square meters (fig. 3 ). The uppermost layer inside the chamber is a light brown sandy soil layer of erosion, L.01, more than $0.60 \mathrm{~m}$ thick. The underlying whitish layer, L.02, formed by the collapse of the roof contained some scattered human bones, and is thick about $0.50 \mathrm{~m}$. These erosion and collapse strata covered the compact brownish sandy soil layer (L.03) with human remains and funerary equipment, $0.35 \mathrm{~m}$ thick.

Unfortunately, due to the collapse of the ceiling human bones were fragmentary preserved, but according to number, kind and dimensions an original deposition of minimum 6 and at least 8 individuals of different ages, young and adult, can be surmised.

The funerary set was arranged in the southeastern corner of the chamber (fig. 4).

Depositions and equipment (L.03) were displaced over a sterile layer, L.04, a $0.10 \mathrm{~m}$ thin layer of brown soil with small stones. The displacement of skeletons and of funerary offerings in the tomb ( $\S 3$.), as well as the burial practices documented ( $\S 5$.), shows that the Khirbet Bir el-Kharayib tomb was a family tomb in use for at least three generations.

\section{THE FUNERARY ASSEMBLAGE}

The Khirbet Bir el-Kharayib tomb has provided an interesting equipment including 10 complete ceramic vessels, ${ }^{4}$ some fragmentary vases, ${ }^{5}$ a zoomorphic figurine and a bronze bowl. Archaeological finds (tab. 1) are presented by classes as follow: bronze ( $\$ 3.1$.), clay figurine ( $\$ 3.2$.), Bichrome Ware pottery ( $\$ 3.3$.), Table and Storage Ware ( $\S 3.4 .-3.5$.), Cooking Ware (§ 3.6.), and pottery for special uses ( $\$ 3.7$.$) .$

\subsection{Bronze bowl SL69 (fig. 5)}

The bronze bowl is the only non-ceramic item accompanying the burials. Unfortunately, it was impossible to associate it to a specific deposition. The bowl, named SL69, has a slightly convex sunken disc base, a curved profile, and an inverted rim marked by a slight groove outside without decorations (fig. 5:c). The diameter of the rim is $17.5 \mathrm{~cm}$, the diameter of the base measures $9.2 \mathrm{~cm}$ and the height is $4.8 \mathrm{~cm}$.

The excavation of the tomb was carried out in two days, between the $19^{\text {th }}$ and $20^{\text {th }}$ of April 2017.

1 Bichrome Ware jug, 2 Black Slip juglets, 3 Red Slip dipper-juglets, and 4 Simple Ware dipper-juglets.

3 Red Slip bowls, 1 Simple Ware bowl, 5 Simple Ware jugs, 1 Black Slip juglet, 1 Red Slip juglet, 4 Simple Ware juglets, 1 Simple Ware dipper-juglet, and 2 Cooking pots. 
This type of bronze bowl is widespread throughout the Levant since the Late Bronze Age II with some variants of the shape of the hammered rim. ${ }^{6}$ The same type then continues with a progressively minor frequency during the Iron Age I and Iron Age II. ${ }^{7}$

In New Kingdom Egypt (XVIII ${ }^{\text {th }}-X^{\text {th }}$ Dynasty) and in the territories of the Levant under the Egyptian influence or affiliation, curved profiled bowls with inner depression in the base are well documented, often as part of metallic wine-set, ${ }^{8}$ and L. Ghersuny noted that «the most and consistent parallels to the Caananite bronze vessels were found in Egypt». ${ }^{9}$

At Cyprus, although they are not a common shape, they are attested mainly during the Cyprus Geometric I-II period (1050-950/950-900 BC). ${ }^{10}$

The most reliable comparisons for bowl SL69 (fig. 6) can be found at the Tel Jatt cave/grave ${ }^{11}$ and at the tombs of Dothan ${ }^{12}$ and Azor, ${ }^{13}$ and it reasonably dated back to the $12^{\text {th }}-10^{\text {th }}$ century BC. ${ }^{14}$

\subsection{Zoomorphic clay figurine SL70 (fig. 7)}

The zoomorphic hollow figurine SL70 with long legs and a cylindrical body represents a quadruped, probably a horse or a bull, but head and tail are missing and there are no details of the harness. Two holes, one in correspondence of the neck and the second at the back, suggest that it was used to pour liquids. No traces of painted decoration are detected. The maximum length of the figurine is $25.8 \mathrm{~cm}$ and the maximum height is $15.8 \mathrm{~cm}$. The

6 For a comprehensive study of metal vessels during the Late Bronze and Iron Ages in Levant see Gershuny 1985.

7 For a wide number of examples of different periods see Gershuny 1985. During the Iron Age II, just a few examples are known. See, for example, the specimen, dated back to the Iron Age IIA, found in a pit-grave at Rasm el-Arus (Abadi-Reiss 2016, fig. 16:2). About the continuity of the metalwork in Levant from the Bronze Age to the Iron Age see Negbi 1974, 159-172.

8 For a comprehensive study of metal vessels in Egypt see Radwan 1983. A silver bowl with similar shape come from the treasure of Tell Basta: Lilyquist 2012, 16-17, 58, fig. 76. See also the bronze bowl from the tomb 114 of Deir el-Balah (Dothan 1978, 22, figs. 41-42) and the specimens from the cemetery of Tell elFarah South (Petrie 1930, 7, pl. 21:93, 97; 9-10, pl. 28:822, 834; 10, pl. 28:615; pl. 30:112). Both the sites were under the direct Egyptian influence during the Late Bronze Age. For some considerations about the role of the bronze wine-sets inside the funerary contexts of the Levant and the assimilation of the Egyptian status symbols within the local traditions during the passage to the early Iron Age see the study about the cemetery of Tell es-Sa'idiyeh by Green (2006, 204-206).

9 Gershuny 1985, 55. Some years later, O. Negbi $(1991,222$; 1998) coined the terms "Egypto-Canaanite" emphasizing the difficulty to assign a precise origin to this kind of vessels. About the typology of the Egyptian-style metallic vessels see also Higginbotham 2000, 171-183.

10 See Matthäus 1985, 115-116, pl. 19:331 (Amathus, Tomb 22.1), 332 (Gastria, Alaas, Tomb 6 or 8), 335 (Lapithos, Kastros, Tomb 409); 2001, 175; Karageorghis 1983, 57-76, figs. LXXIII-XC (Palaepaphos-Skales, Tomb 49); 241-250, figs. CXLIX-CLI, CLVI (Palaepaphos-Skales, Tomb 79). For an update of the Cyprus chronology see Georgiadou 2016.

11 Artzy 2006, 28-29, 55-56, pl. 2:J-37, J-38, J-39, J-70.

12 Gershuny 1985,7, n. 31, pl. 4:48, 50, 52

13 Ben-Shlomo 2008a, 40, 46, fig. 21:1.

14 A similar bowl was also found at Achziv into the cist tomb 1029 dated to the $11^{\text {th }}$ century BC (Prausnitz 1997, tab. 2:1). 
fabric is rough with frequent white medium-size grits and straw. Due to its dimensions and shape it may be also interpreted as a cult libation vessel, like a rhyton or an askos. ${ }^{15}$

Clay figurines, quite common in the Iron Age tombs, have a twofold interpretation: as toys, when in infant burials, ${ }^{16}$ and as cult items related with the funerary ritual.

At Cyprus, similar shaped animal figurines used as votive offerings are well documented in the Sanctuary of Agia Irini and the majority are dated back to the Cyprus Geometric III period (900-750 BC). ${ }^{17}$

SL70 can be dated to the Iron Age IIA according to the comparison with a hollow figurine from Tel Moza. ${ }^{18}$

\subsection{Bichrome Ware (BW) jug SL68 (fig. 8)}

BW jug SL68 presents an everted rim with an up-right tapered lip, ridged neck, globular body, and ring base. The handle is attached from the shoulder just below the ridge on the neck. The jug has a geometric bichrome decoration with horizontal red and black lines on the rim, the neck and the body, and metopae on the shoulder. The handle is decorated with thick horizontal red lines. The jug is $26.2 \mathrm{~cm}$ high, the maximum body diameter is $18.4 \mathrm{~cm}$, the rim diameter measures $8.5 \mathrm{~cm}$ and the base $5.6 \mathrm{~cm}$. The fabric is depurated with a few white small grits.

BW neck-ridge jugs with globular body are a typical Phoenician production, and a Phoenician hallmark as already stated by W.P. Anderson. ${ }^{19}$ Furthermore, as pointed out by S.V. Chapman, these jugs are not a homogeneous group, and in the Levant the number of the examples known and their spatial distribution are limited. ${ }^{20}$

BW jugs of this type are attested to in Phoenicia, at Tyre (Strata X-2-VIII), in al-Bass necropolis (Period II) and Sarepta (Levels D-1 and D-2), ${ }^{21}$ and, at the same times, in Palestine, specifically in the cities with a presence of Phoenician or coastal material, as

15 Differently from most of the zoomorphic vessels of the Iron Age II characterized by short hand-molded legs, a raised rim sometimes enriched with an upright handle and a "barrel-shaped" wheel-made body, as well documented at Megiddo (Stratum VA-IVB; Finkelstein - Zimhoni - Kafri 2000, 287-289, fig. 11.33:10), Horbat Rosh Zayit (Stratum IIa; Gal - Alexandre 2000, 80-81, 116-117, fig. III.92:1), Lachish (Tomb 218; Tufnell 1953, 203-209, fig. 25), Tell Beit Mirsim (Stratum A; Albright 1941, pls. 27b:1, 58:1), Tsur Natan (Tomb L2; Alon - Herriot - Varoner 2013, 26-28, fig. 4.3) and in Philistine and Phoenician areas (see for example: Ben-Shlomo 2008b, 30-31, fig. 5:1; Bikai 1978, pl. LXXXIII:6), the SL70 item has different morphological and technological features: the body has a narrow cylindrical shape, not suitable to contain large quantities of liquids - contra "barrel-shaped" body -, and both, body and legs, are hand-made. For a general study of the zoomorphic vessel of the second millennium BC in Levant see Gershuny 1991.

16 Yezerski - Geva 2003, 64.

17 Papantoniou - Bourogiannis 2018, 5.

18 Kisilevitz 2015, 158-159, fig. 6. With its peculiar hole on the back, the figurine from Khirbet Bir el-Kharayib could be considered as a variant of the common type known as "horse rider figurines": in this kind of figurine, generally the bodies of the horse and rider were handmade separately and then attached before firing (Yezerski 2010, 105).

19 «One of the more recognizable shapes attributed to the Phoenicians» (Anderson 1990, 41).

20 See Chapman 1972, 82-84 for the BW jugs from Khirbet Silm and Joya (Lebanon). F. Nuñez Calvo summarized the devolvement of this jug and offered a chronological proposal (Nuñez Calvo 2008-2009, 52).

21 Respectively: Bikai 1978, pls. XX, XXI, XXV; Nuñez Calvo 2014, 276-277, fig. 3.21; Pritchard 1975, fig. 20. 
Megiddo (Stratum VA-IVB), Hazor (Stratum IX), Horbat Rosh Zayit (Stratum IIa), Tell Abu Hawam (Stratum III) and Samaria (Periods III-IV). ${ }^{22}$

Basing on the morphology and the decoration, the closest parallels are two jugs from the necropolises of Joya and Khirbet Silm. ${ }^{23}$

As regards the decorative pattern, the metopal design and the irregular strokes on the back of the handle are frequent features of jugs, decanters and craters starting from the Late Bronze Age which continue during the Early Iron Age, while the presence of a band at the base of the neck is a typical element of the decorative repertoire of the Early Iron Age Phoenician repertoire. ${ }^{24}$ This decorative syntax can be detected in some examples from Khirbet Silm, Joya, Tell Abu Hawam (Stratum III), Megiddo (Stratum VA-IVB) and Mont Carmel (Tomb 2) dating into the first half of the $9^{\text {th }}$ century BC..$^{25}$

Regarding the morphological features, the rim with up-right lip, the globular body and the ring base are typical of the Phoenician repertoire between Early Iron Age and Late Iron Age. The transition is well documented in Phoenicia, at al-Bass cemetery (Period II), ${ }^{26}$ and in Cyprus, from the end of Kouklia and the beginning of Salamis horizons (925-850 BC). ${ }^{27}$

In summary, jug SL68 shows both, some conservativism in the decorative apparatus, and a later shape of the rim and the neck which is common in Late Iron Age. Therefore, the BW jug can reasonably be dated to the Iron Age IIA, a period of innovation and change into the Phoenician ceramic repertoire. ${ }^{28}$

\subsection{Bowls (fig. 9)}

Four fragmentary bowls were discovered into the tomb. Except for one Simple Ware (SW) specimen ${ }^{29}$ (fig. 9:4.), the bowls are matt slip in orange, reddish brown or light-red tones and the surface is in general horizontally, slightly irregular, hand-burnished.

An almost complete bowl (fig. 9:1) with an angled thickened rim, low sharp carination, rounded walls and disc base finds parallels in the Northern Levant at Hazor (Stratum IXa), Megiddo (Strata VB and VA-IVB), Samaria (Period II), Horbat Rosh Zayit (Strata IIa-I) and Beth Shean (Stratum, S-1a), and it is dated in a wide chronological range between the second half of the $10^{\text {th }}$ and the second half of the $9^{\text {th }}$ centuries $\mathrm{BC}$.

Deep bowl with slightly out-turned rim, low rounded carination, splayed upper sidewall and wide ring base (fig. 9:2) has comparisons within the ceramic repertoire of Megiddo

22 Respectively: Finkelstein - Zimhoni - Kafri 2000, 281-282, fig. 11.32:5; Ben-Ami 2012, fig. 2.21:9; Gal Alexandre 2000, 114-115, fig. III.91:10; Herrera - Gómez 2004, 374, pl. XXX:257; Kenyon 1957, 111, fig. $5: 1$.

23 Chapman 1972, 82-84, fig. 8:43-45, 190.

24 As noted by F.J. Nuñez Calvo (2008-2009, 58).

25 Chapman 1972, 82-84, fig. 8:43-45, 190; Herrera - Gómez 2004, 374, pl. XXX:257; Finkelstein - Zimhoni Kafri 2000, 281-282, fig. 11.32:5; Guy 1924, 50, pl. II: 11.

26 Nuñez Calvo 2014, 276-277.

27 Bikai 1987, 17, pl. X:177.

28 See also E. Arie (2013a) about the first appearance of this type of jug: «One of the marked developments in the Phoenician bichrome group is the appearance, during the Iron IIA, of the globular jug with the ring base. In their studies of the Phoenician bichrome group, Anderson (1990) and Gilboa (2001) demonstrate that this type appears only during the Iron IIA» (Arie 2013a, 701).

29 Regarding the specimen at fig. 9:4, the state of preservation does not permit to exactly establish the typology. 
(StrataVB and VA-IVB), Samaria (Periods III-VI), Horbat Rosh Zayit (Stratum IIb), Beth Shean (Level V/Stratum, S-1a) and Tell Beit Mirsim (Tomb 101). ${ }^{30}$ Such a kind of bowl is one of the most reliable chronological markers of Early Iron Age II and can be dated into the end of $10^{\text {th }}$ and the early $9^{\text {th }}$ centuries BC..$^{31}$

Finally, the hemispherical bowl with simple rim, rounded base and very thin walls (fig. 9:3 ${ }^{32}$ finds numerous parallels at Hazor (Stratum IXa), Megiddo (Stratum K-3), Horbat Rosh Zayit (Stratum IIa-I), Beth Shean (Stratum, S-1a), Tel Moza (Stratum V) and Lachish. It is dated to the $10^{\text {th }}-9^{\text {th }}$ century BC. ${ }^{33}$

To conclude, the bowl types from the tomb of Khirbet Bir el-Kharayib are attested to the Levant during the Iron Age IIA and declined throughout the Iron Age IIB.

\subsection{Simple Ware jugs and jars (fig. 10)}

Five jugs and jars have been uncovered into the tomb.

All the specimens are Simple Ware and there is not any evidence of coating or decorative motifs on the exterior surface; just one specimen (fig. 10:2) is vertically handburnished.

The jugs in fig. 10:1-2 have a simple thickened rim, slightly flared cylindrical neck, ovoid or rounded body and single handle from the rim to the shoulder. They belong to a common type which spread over the Levant during the Iron Age II. Worthy comparisons are in the repertoire of Horbat Rosh Zayit (Stratum I), Tell el Far'ah North (Stratum VIIb) and Lachish (Strata V). They date in $9^{\text {th }}$ century BC, although the type is attested at least since the $11^{\text {th }}$ century BC..$^{34}$

The jug/jar in fig. 10:3, with simple rim, narrow vertical neck and upper slight ridge under the rim, ${ }^{35}$ is well documented during the Iron Age I and less frequent in the latter periods. ${ }^{36}$ It finds reliable parallels in the ceramic repertoire of Horbat Rosh Zayit (Stratum I), Gezer (Stratum VIIa) and Beth Shean (Stratum S-1a). ${ }^{37}$

30 Finkelstein - Zimhoni - Kafri 2000, 274-275, fig. 11.23:17; 284-285, fig. 11.30:8; Kenyon 1957, 108, fig 4:11; Gal - Alexandre 2000, 86-87, fig. III.87:12; James 1966, 268-269, fig. 63:7, Mazar 2006, 404-405, pl. 9:9-10; Ben-Arieh, 2004, 78, fig. 2.46:4.

31 Stern 2015, 436-437.

32 Mazar 2006, 326-327, BL55.

33 Ben-Ami 2012, fig. 2.18:13; Finkelstein - Zimhoni - Kafri 2000, 260-263, fig. 11.18:4; Gal - Alexandre 2000, 108-109, fig. III.87:14; 142-143, fig. III.121:13; Mazar 2006, 404-405, pl. 9:6; Greenhut - De Groot 2009, 79 85, figs. 3.11:3 and 3.13:6; Tufnell 1953, pl. 81:94-95

34 Gal - Alexandre 2000, 144.145, fig. III.122:14; Tappy 2015, 206-208, pl. 2.3.9:3; Aharoni 1975, pl. 42:1,5. For other comparisons see also: Ben-Tor - Zarzecki-Peleg 2015, 179-180, pl. 2.2.16:1; Herzog - Singer-Avitz 2015, 232-233, pl. 2.4.7:1

35 Type 2 can be related with the GR7 type of the typological classification of the ceramic repertoire of the Iron Age at Tel Dor proposed by A. Gilboa (2018, 122. 84, pl. 20.xviii, GR7).

36 Mazar 2015, 44-47, pl. 1.1.6:6-8; 52-53, pl. 1.1.21:9; Zukerman - Gitin 2016, 374-375, fig. 5.96:2; Gadot 2009, 306-307, fig. 8.72:22; Guy 1938, pls. 8:13, 72:12.

37 Gal - Alexandre 2000, 144-145, fig. III.122:13; Gitin 1990, pl. 9:10; Mazar 2006, 406-407, pl. 10:5. 
Finally, bow rim is a frequent morphological feature of jugs, cooking jugs and jars (fig. $10: 4-5)^{38}$ since the Iron Age I, and it is attested without any significative change from the $12^{\text {th }}$ to the $9^{\text {th }}$ century BC..$^{39}$

To sum up, the jugs and jars of Khirbet Bir el-Kharayib tomb are dated to the Iron Age IIA with a possible chronological shift into the early Iron Age IIB.

\subsection{Cooking pots (fig. 10)}

Two fragmentary cooking pots, different in shape and dimension, were within the funerary furnishing the Khirbet Bir el-Kharayib tomb. ${ }^{40}$

The first (fig. 10:6) is an open pot with a short triangular-shaped rim and probably a squatted body. The type is attested since the $10^{\text {th }}-9^{\text {th }}$ century BC and also at Samaria (Period VI). R.E. Tappy recently dated back the type to the late $10^{\text {th }}$ century BC. ${ }^{41}$

The second pot (fig. 10:7) has a straight rim with a slight ridge below and a squatted slightly carinated body. Traces of fire are visible on the exterior surface. No handles have been detected. The type is attested from the Iron Age I to the Iron Age IIB, with major attestations during the Iron Age IIA. ${ }^{42}$

\subsection{Juglets and dipper-juglets (figs. 11-12)}

Juglets and dipper-juglets are the most attested ceramic class in the funerary equipment of Bir el-Kharayib tomb (16 vessels) and they can be classified in three types: Black Slip juglets (§3.7.1.), juglets (§ 3.7.2.) and dipper-juglets (§3.7.3.).

\subsubsection{Black Slip (BS) juglets}

Three BS juglets were recovered into the tomb. They are $10.2 \mathrm{~cm}$ high, the rim diameter is $2.4-2.8 \mathrm{~cm}$, the maximum diameter is $6.4-7 \mathrm{~cm}$ and they are vertically hand-burnished.

The juglet SL81 (fig. 11:1) is with globular body, button-base, long narrow straight neck, simple rim and handle from the shoulder to the middle of the neck, ${ }^{43}$ but the rim and the handle are missing. This kind of juglet is the earliest variety of BS juglets, and spread over the Levant since the Iron Age I. ${ }^{44}$ It can be compared with examples from Hazor

38 For jugs with this peculiar shape of the rim see for example: Ben-Shlomo 2008a, 44, fig. 18:7; Gitin 1990, pls. 4:22, 7:6, 8:3. For some examples of jars with this kind of rim see: Ben-Tor - Zarzecki-Peleg 2015, 167-169, pl. 2.2.10:10; Herr 2015, 295, pl. 2.6.9:4; Lehmann 2015, 122-124, pl. 2.1.3:4; Mazar 2006, 416-417, pl. 15:14.

39 Ben-Shlomo 2008a, 42-44. Type 3 can be related with the GR4 type of the typological classification of the ceramic repertoire of the Iron Age at Tel Dor proposed by A. Gilboa (2018, 122, 84, pl. 20.xviii, GR4).

40 For a comprehensive typological study about the cooking pots in the Levantine and Cypriote areas between the Late Bronze and Iron Ages, see Spagnoli 2010.

41 Tappy 2015, 192, 202-203, pl. 2.3.5:2; Kenyon 1957, fig. 9:11. For a possible comparison in Transjordan, see also: Herr 2015, 283, 292, pl. 2.6.6:5.

42 Spagnoli 2010, 13.

43 Type A generally corresponds to Type C-3 of J.L. Kelley classification (Kelley 2014, 200-204) and to O. Tufnell class D.7a (Tufnell 1953, 301-303, 328); see also the classification proposed by R. Amiran (1970, 256-265).

44 Tufnell 1953, 303; Kelley 2014, 357, 369 and 226-228, figs. 4.12-4.14; contra Amiran 1970, 256: «The socalled "black" juglets make their appearance in Iron II". 
(Stratum Xa), Megiddo (Stratum VA-IVB), Tell en-Nasbeh (Tomb 106), Tell el Far'ah North (Stratum VIIb), Horbat Rosh Zayit (Stratum IIa), Lachish (Tomb 521) and Beer Sheba (Stratum VI).The BS juglet is dated to the end of $10^{\text {th }}$-first half of the $9^{\text {th }}$ century BC. ${ }^{45}$

Juglets as SL84-85 (fig. 11:2-3) with globular body, rounded base, flared neck with simple or inverted rim and handle from the shoulder to the upper part of the neck under the rim $^{46}$ are one of the commonest types attested to Palestine during the Iron Age IIA-B. ${ }^{47}$ They can be compared with some specimens from Megiddo (Stratum VA-IVB), Tell el Far'ah North (Stratum VIIb), Horbat Rosh Zayit (Stratum IIa), Lachish (Tomb 218), Tell Beit Mirsim (Stratum B and Tomb 101) and Beer Sheba (Stratum VI) ${ }^{48}$ moreover, some other examples are attested to Khirbet Silm and Joya. ${ }^{49}$

As it regards diagnostic feature of dipper juglets, R. Amiran noted that the handle position has a chronological significance: ${ }^{50}$ in earlier specimens the handle is attached to the central part of the neck or simply below the rim to the shoulder. In later juglets the handle is jointed to the rim. The examples from Bir el-Kharayib with the junction point of the handle in the middle of the neck can be dated to the Iron Age IIA, as SL81, those with the handle below the rim, as SL84 and 85, could be slightly later.

\subsubsection{Black-on-Red (BoR) and Simple Ware (SW) juglets}

Five specimens belong to this group. They have a globular or fusiform body, narrow and straight neck, simple rim, and button-base.

The BoR juglet ${ }^{51}$ SL80 (fig. 11:4) shows four black painted bands on the body. The juglet from Khirbet Bir el-Kharayib tomb seems to be a local imitation of the Cypriot Black on Red, due to the characteristic decorative pattern applied on a typical Levantine shape. Imitations of BoR are quite rare in Palestine, and just a limited number of specimens generally dated back to the Iron Age IIA/early Iron Age IIB are detected (900/875-825 BC). 52

Other juglets (fig. 11:5-8) do not show any surface treatment. As regards the typology, these juglets find numerous comparisons in the Iron Age II Levant repertoires, ${ }^{53}$ e.g. at

45 Respectively: Ben-Ami 2012, fig. 2.8:27; Finkelstein - Zimhoni - Kafri 2000 287-289, fig. 11.33:1; 296-297, fig. 11.39:1; Wampler 1947, pl. 41:805, Chambon 1984, pl. 50:18-22; Gal - Alexandre 2000, 65-66, Type JT IV; 105-106, fig. III.85:12; Tufnell 1953, pl. 88:328; Herzog 1984, 60-61, fig. 30:6-7.

46 Type B corresponds to Type B-2 of J.L. Kelley classification (Kelley 2014, 183-186) and to O. Tufnell class D.7b (Tufnell 1953, 301-303, 328).

47 Kelley 2014, 185-186, 226-228, figs. 4.12-4.14.

48 Finkelstein - Zimhoni - Kafri 2000, 296-297, fig. 11.39:5; Chambon 1984, pl. 50:10, 13; Gal - Alexandre 2000, 65-66, Type JT III; 105-106, fig. III.85:10-11; Tufnell 1953, pl. 88:324; Albright 1931, 145, pl. 51:8; Ben-Arieh 2004, 21, 79, fig. 2.57:26-28; Herzog 1984, 60-61, fig. 30:5.

49 Chapman 1972, 141-142, fig. 30:159, 263.

50 Amiran 1970, 256, 259.

51 About the BoR Ware in Levant, the state of art and the discussion on its origin, chronology and stylistic development see Kleiman et al. 2019.

52 Finkelstein - Zimhoni - Kafri 2000, 280-281, fig. 11.27:8; Tufnell 1953, pl. 88:325; Herr 2015, 296-297, pl. 2.6.10:13.

53 Rarely attested during the Iron Age I (Arie 2013b, 208, Type JT3, fig. 13.29). 
Megiddo (Strata VB and VA-IVB), Horbat Rosh Zayit (Stratum IIa) and Lachish (Tomb 518). ${ }^{54}$

\subsubsection{Red Slip (RS) and Simple Ware (SW) dipper juglets}

Dipper juglets represent the most numerous and homogeneous group of vessels found in the tomb. Eight specimens were found in the tomb: three RS (figs. 11:9-10 and 12:4) and five SW (fig. 12:1-6). The RS and three of the SW specimens (fig. 12:1-2, 5) are vertically burnished. They can have either simple or pinched rim, straight or flared neck, oval body with a slightly carination on the shoulder and rounded or slightly pointed base. The handle is directly jointed from the shoulder to the rim.

Dipper juglets of such kind are attested to Hazor (Strata X-IX), Megiddo (Stratum VAIVB); Horbat Rosh Zayit (Strata IIb-I), Samaria (Periods I-VI), Beth Shean (Level V), Rasm el-Arusm and Lachish (Tombs 107 and 1002) in contexts dated to the end of $10^{\text {th }}$ and the $9^{\text {th }}$ century BC. ${ }^{55}$

The dipper juglet is a common type during the Iron Age $\mathrm{II}^{56}$ although it is regularly attested also in the Iron Age I, as it belongs to the ceramic traditional repertoire of the Bronze Age Levant. ${ }^{57}$ The morphological features and the comparisons allow to date the Bir el-Kharayib dipper juglets between the Iron Age IIA and early Iron Age IIB (925-825 $\mathrm{BC})$.

\section{FINAL REMARKS}

On the basis of the material evidence considered so far, the funerary assemblage from Khirbet Bir el-Kharayib tomb vividly depicts cultural interactions and ancient trade in central Levant during the Iron Age II, and offers some sparks of new data into the long debate regarding this period and its periodization and setting in absolute chronology. In fact, the province of Salfit, in which Khirbet Bir el-Kharayib arises, is located at the border of Judea and Samaria, and is crossed by an important route running north-south that connected Jerusalem to Shechem and Samaria. ${ }^{58}$ Furthermore, this area is a cross passage for trades with the Phoenician cities of the coast.

The pottery from the tomb is deeply enrooted within the ceramic tradition of the sites of the Northern Palestine and in particular with Hazor (X-IX), Megiddo (VB/VA-IVB), Horabat Rosh Zayit (IIa-I) and Samaria (III). Nevertheless the connections from the South and the Centre is also marked by the parallels with the repertoire of Lachish (V-IV), Beer

54 Finkelstein - Zimhoni - Kafri 2000, 277-279, fig. 11.26:2 and 5; 296-297, fig. 11.39:2; Gal - Alexandre 2000, 96-97, fig. III.80:14; 105-106, fig. III.85:13; 112-113, fig. III.90:12; Tufnell 1953, pl. 88:325 (Red Slip juglet with a linear painted black decoration).

55 Aharoni et al. eds. 1960, pl. LII:16 (RS); Ben-Tor - Bonfil eds. 1997, 251-254, fig. III.32:13 (SW); Finkelstein - Zimhoni - Kafri 2000 296-297, fig. 11.39:10 and 13 (RS); 304-306, fig. 11.46:3 (SW); Gal Alexandre 2000, 86-87, fig. III.74:1-4 (SW and RS); 110-111, fig. III.88:11-12 (SW); 141-145, fig. III.122:16-17 and 19-20 (SW and RS); Kenyon 1957, 99-100, fig. 1:7; 122-125, fig. 10:20-22; James 1966, 254-265, fig. 61:2 (RS); Tufnell 1953, pl. 88:291 and 300 (SW and RS); Abadi-Reiss 2016, fig. 14:1-2 (SW).

56 Arie 2013a, 705.

57 Arie 2013b, 207.

58 Nigro et al. 2015, 140. 
Sheba (V) and Beth Shean (V/S-1a) and strict connections are detectable even with the ceramic repertoire of Tyre (IX-VIII) and Tell Abu Hawam (III). In term of relative chronology, the context is dated to the Iron Age IIA, corresponding, from a ceramic point of view, to the transition between the Kouklia and Salamis horizons at Cyprus. ${ }^{59}$

In this paper, according to the Levantine New Chronology pursued by L. Nigro, ${ }^{60}$ the funerary assemblage from Khirbet Bir el-Kharayib can be dated into the end of $10^{\text {th }}$-first half of the $9^{\text {th }}$ century BC $(925-850$ BC) although some material, as the Black Slip juglets, (fig. 10:2-3) suggests a lower chronological limit in the second half of the $9^{\text {th }}$ century BC (early Iron Age IIB).

Despite this, the bronze bowl SL69 should be dated slightly earlier of the Iron Age II; it might be related to a previous deposition or might represent a hoarded luxury good.

According to the multiple deposition and the kind of the funerary equipment the tomb seems to represent a family burial place lasted in use for more than a century.

Finally, although the funerary ceramic assemblage respects the Palestine standard of the Iron Age II, the absence of some typically funerary classes as the lamps is probably related to the local (familiar or tribe?) funerary ritual and burial practices. ${ }^{61}$

To sum up, the Khirbet Bir el-Kharayib tomb is a meaningful example of the cultural mixture in central Palestine during the Iron Age and of how the material culture and especially the tomb furnishings are what of is the most alien from being a cultural label or a unique "identity" interpretation.

\section{REFERENCES}

ABADI-REISS, $\mathrm{Y}$

2016 Rasm el-'Arus: Hadashot Arkheologiyot. Excavation and Surveys in Israel 128 (2016), digital journal.

AHARONI, Y http://www.hadashot-esi.org.i1/report_detail_eng.aspx?id=24930\&mag_id=124

1975 Lachis V. Investigation at Lachish. The sanctuary and the residency (Tel Aviv University, Publication of the Institute of Archeology 4), Tel Aviv 1975.

Aharoni Y. - Amiran R. - Dothan, T. - DunAyevsky, I. - Perrot, J. (eds.)

1960 Hazor II: an account of the second season of excavations, 1956 (The James A. de Rothschild Expedition at Hazor, The Hebrew University of Jerusalem), Jerusalem 1960.

AlbRight, W.F.

1931 The Excavation of Tell Beit Mirsim. Vol. I: The Pottery of the First Three Campaigns: The Annual of the American Schools of Oriental Research 12 (1931), pp. 1-165.

59 This intermediate period is well expressed by the Bichrome Phoenician jug SL68 which has a decorative pattern that finds parallels in the Late Iron Age I/early Iron Age II while similar morphological features are attested at the beginning of the Salamis horizon at Cyprus.

60 Nigro 2014, 261-267. About the chronological debate on the Iron Age in the Levant and the synthesis of the different proposals see Nuñez Calvo 2016, 73-77, in particular fig. 1 .

61 Bloch-Smith $(1992,74,77)$ explains how the absence of lamps - or the gradually reduction of specimens - in the standard ceramic funerary assemblage starting from the $10^{\text {th }}$ century BC is a common feature of the centres of the coastal plain such as Achziv, Ashdod and Deir el-Balah or with the burial practice, in particular with the pit-graves. 
1941 The Excavation of Tell Beit Mirsim. Vol. III: The Iron Age: The Annual of the American ALEXANDRE, Y Schools of Oriental Research 21/22 (1941), pp. 1-229.

2007 Iron Age IIA Remains from a Salvage Excavation at Sulam: Atiqot 56 (2007), pp. 23-32.

Alon, S. - Herriot, C. - VARONER, O.

2013 Excavation at Tsur Natan - 2011. An Iron Age Tomb, Byzantine Quarry and Other Remains: D. ILAN (ed.), The Nelson Glueck School of Biblical Archaeology, Vol. 2, Jerusalem 2013, pp. 9-66.

AMIRAN, R.

1970 Ancient Pottery of the Holy Land. From its Beginnings in the Neolithic Period to the End of the Iron Age, New Brunswick 1970.

ANDERSON, W.P.

1990 The Beginnings of Phoenician Pottery: Vessel Shape, Style, and Ceramic Technology in the Early Phases of the Phoenician Iron Age: Bulletin of the American Schools of Oriental Research 279 (1990), pp. 35-54.

ARIE, E.

2013a The Iron Age IIA pottery: I. FinKelsteIn - D. Ussishrin - E.H. Cline (eds.), Megiddo V. The 2004-2008 Seasons (Monograph Series under the auspice of the Friends of the Institute of Archaeology of Tel Aviv University), Vol. II, Tel Aviv 2013, pp. 668-828.

2013b The Iron Age I pottery: Levels K-5 and K-4 and an intra-site spatial analysis of the pottery from Stratum VIA: I. FINKELSTEIN - D. UssishKIN - E.H. CLINE (eds.), Megiddo V. The 2004-2008 Seasons (Monograph Series under the auspice of the Friends of the Institute of Archaeology of Tel Aviv University), Vol. II, Tel Aviv 2013, pp. 191-298.

ARTZY, M

2006 The Jatt metal hoard in Northern Canaanitel Phoenician and Cypriote context BEN-AMI, D. (Cuadernos de Arqueología Mediterránea 14), Barcelona 2006.

2012 The early Iron Age II (Strata X-IX): T. KuPER-BlaU (ed.), Hazor VI. The 1990-2009 Excavations. Iron Age (The Selz Foundation Hazor Excavations in memory of Yigael Yadin), Jerusalem 2012, pp. 52-153.

BEN-AMI, D. - BEN-ToR, A.

2012 The Pottery of Strata X-IX: T. KuPER-Blau (ed.), Hazor VI. The 1990-2009 Excavations. Iron Age (The Selz Foundation Hazor Excavations in memory of Yigael Yadin), Jerusalem 2012, pp. 441-503.

BEN-ARIEH, S.

2004 Bronze and Iron Age Tombs at Tell Beit Mirsim (Israel Antiquities Authority Reports 23), Jerusalem 2004.

BEN-SHLOMO, D.

2008a The Cemetery of Azor and Early Iron Age Burial Practices: Levant 40 (2008), pp. 29-54.

2008b Zoomorphic Vessels from Tel Miqne-Ekron and the Different Styles of Philistine Pottery: Israel Exploration Journal 58 (2008), pp. 24-47.

2012 The Azor Cemetery:Moshe Dothan's excavations 1958 and 1960 (Israel Antiquities Authority Reports 50), Jerusalem 2012. 
BEN-ToR, A - BonfIL, R. (eds.)

1997 Hazor V: an account of the fifth season of excavations, 1968 (The James A. de Rothschild Expedition at Hazor, The Hebrew University of Jerusalem), Jerusalem 1997.

Ben Tor, A. - ZARZECKI-PELEG, A.

2015 Iron Age IIA-B: Northern Valleys and Upper Galilee: S. GiTIN (ed.), The Ancient Pottery of Israel and Its Neighbors, from the Iron Age through the Hellenistic Period, Vol. 1, Jerusalem 2015, pp. 135-188.

BIKAI, P.M.

1978 The Pottery of Tyre, Warminster 1978.

1987 The Phoenician Pottery of Cyprus, Nicosia 1987.

BLOCH-SMITH, E.

1992 Judahite Burial Practices and Beliefs about the Dead (Journal for the Study of Ancient Testment, Monograph Series 7), Sheffield 1992.

Chambon, A.

$1984 \quad$ Tell el Far'ah I : l’Âge du Fer (Mémoire 31), Paris 1984.

CHAPMAN, S.V.

1972 A catalogue of Iron Age pottery from the cemeteries of Khirbet Silm, Joya, Qrayé and Qasmieh of South Lebanon. With a note on the Iron age pottery of the American DOTHAN, T. University Museum, Beirut: Berytus XXI (1972), pp. 55-194.

1978 Excavations at the Cemetery of Deir el-Balah: Qedem 10 (1978), pp. 1-114.

DOUMANI, B.

1995 Rediscovering Palestine: Merchants and Peasants in Jabal Nablus, 1700-1900, California 1995.

ELLENBLUM, R.

2003 Frankish Rural Settlement in the Latin Kingdom of Jerusalem (Cambridge OCR Advanced Science), Cambridge 2003.

FinKELSTEIN, I. - LEDERMAN, Z. (eds.)

1997 Highlands of many cultures. The Southern Samaria survey: The Sites (Monograph Series of the Institute of Archaeology of Tel Aviv 14), Tel Aviv 1997.

FINKELSTEIN, I. - ZIMHONI, O. - KAFRI, A.

2000 The Iron Age pottery assemblages from Areas F, K and H and their stratigraphic and chronological implications: I. FINKELSTEIN - D. USSISHKIN - B. HALPERN (eds.), Megiddo III: The 1992-1996 Seasons (Sonia and Marco Nadler Institute of Archaeology of Tel Aviv University, Monograph Series 18), Tel Aviv 2000, pp. 244-324.

GADOT, Y

2009 Late bronze and Iron Age Pottery: E. BRAUn (ed.), Aphek-Antipatris II. The remains on the Acropolis. The Moshe Kochavi and Pirhiya Beck Excavations (Sonia and Marco Nadler Institute of Archaeology Tel Aviv University, Monograph Series 4), Tel Aviv 2009, pp. 182-341.

GAL, Z. - AlEXANDRE, Y.

$2000 \quad$ Horbat Rosh Zayit. An Iron Age Storage Fort and Village (Israel Antiquities Authority Reports 8), Jerusalem 2000.

GEORGIADOU, A.P.

2016 Pottery of Geometric, Archaic and Classical Periods in Cyprus: Kyprios Character. History, Archaeology \& Numismatics of Ancient Cyprus. Kyprioscharacter.eie.gr/en/t/A0. 
GERSHUNY, L.

1985 Bronze Vessels from Israel and Jordan: H. MÜLlER-KARPE (hrsg.), Prähistorische Bronzefunde II.6, Mūnchen 1985, pp. 1-63.

1991 Zoomorphic Clay Vases and Rhyta in Israel of the 2nd Millennium BCE (unpublished $\mathrm{PhD}$ thesis), Jerusalem.

GILBOA, A.

2001 Southern Phoenicia during the Iron Age I-IIA in the Light of the Tel Dor Excavations: GREEN, J.D.M The Evidence of Pottery (Unpublished $\mathrm{PhD}$ dissertation), Jerusalem.

2006 Ritual and social structure in the Late Bronze and Early Iron Age Southern Levant: The Cemetery at Tell es-Sa 'idiyeh, Jordan, Vols. 2, PhD thesis, London 2006.

Greenhut, Z. - De Groot, A.

2009 Chapter 3: The Pottery: Z. Greenhut - A. De Groot (eds.), Salvage Excavations at Tel Moza - The Bronze and Iron Age Settlements and Later Occupations (Israel Antiquities GilboA, A. Authority Report 39), Jerusalem 2009, pp. 61-110.

2018 The Iron Age Pottery of Phases 10-5: Sequence, Contexts, Typology, Cultural Affinities and Chronology: G. Garfinkel - N. Goring-Morris - N. PANiTZ-Cohen - Z. Weiss (eds.), Excavation at Dor, Final Report. Volume IIB. Area $G$, the Late Bronze and Iron Ages: Pottery, Artifacts, Ecofactors and Others Studies (Qedem Reports 11), 2018, pp. 97-172.

GiTin, S.

1990 Gezer III. A Ceramic Typology of the Late Iron II, Persian and Hellenistic Periods (Annual of the Nelson Glueck School of Biblical Archaeology), Jerusalem 1990.

GuY, P.L.O.

1924 Mt.Carmel an Early Iron Age Cemetery Near Haifa, Excavated September 1922: Bulletin of British School of Archaeology in Jerusalem 5 (1924), pp. 44-57.

1938 Megiddo Tombs (Oriental Institute Publications XXXIII), Chicago - Illinois 1938.

HERR, L.G.

2015 Iron Age IIA-B: Transjordan: S. Gitin (ed.), The Ancient Pottery of Israel and Its Neighbors, from the Iron Age through the Hellenistic Period, Vol. 1, Jerusalem 2015, pp. 281-299.

HERRERA, M.D. - GÓMEZ, F.

2004 Tell Abu Hawam (Haifa, Isral). El horizonte fenicio del Stratum III británico, Huelva 2004.

HERZOG, Z.

1984 Beer Sheba II. The Early Iron Age settlement (Publications of the Institute of Archaeology 7), Tel Aviv 1984.

HERZOG, Z. - SINGER-AvITZ, L.

2015 Iron Age IIA-B: Huda and the Negev: S. Gitin (ed.), The Ancient Pottery of Israel and Its Neighbors, from the Iron Age through the Hellenistic Period, Vol. 1, Jerusalem 2015, pp. 213-255.

HigGinBOTHAM, C.R.

2000 Egyptianization and Elite Emulation in Ramesside Palestine. Governance and Accomodation on the Imperial Periphery (Culture and History of the Ancient Near East 2), Leiden - Boston - Köln 2000.

HÜTTEROTH, W.-D. - ABDULFATTAH, K.

1977 Historical Geography of Palestine, Transjordan and Southern Syria in the late $16^{\text {th }}$ century (Erlanger Geographische Arbeiten 5), Erlangen 1977. 
JAMES, F.W.

1966 The Iron Age at Beth Shan. A study of Levels VI-V (Museum Monographs), Philadelphia 1966.

KARAGEORGHIS, V.

1983 Palaepaphos-Skales, an Iron Age Cemetery in Cyprus (Alt-Paphos auf Cypren 3), Konstanz 1983.

Kelley, J.L.

2014 The "black" juglets in Iron Age II Palestine: a collation of finds and an analysis of KENYON, K.M. typology, chronology, technology, and distribution, Jerusalem 2014.

1957 Pottery: Early Bronze and Israelite: J.W. CROwFOOT - G.M. CROWFOOT - K.M. KenYON KISILEVITZ, $\mathrm{S}$ (eds.), The Objects from Samaria (Palestine Exploration Fund), London 1957, pp. 90-134.

2015 The Iron Age II Judahite Temple at Tel Moza: Tel Aviv 42 (2015), pp. 147-164.

Kleiman, A. - Fantalikin, A. - Mommsen, H. - Finkelstein, I.

2019 The Date and Origin of Black-on-Red Ware: The View from Megiddo: American Journal LEHMANN, G. of Archaeology 123/4 (2019), pp. 531-555.

2015 Iron Age IIA-B: Northern Coastal Plain: S. Gitin (ed.), The Ancient Pottery of Israel and Its Neighbors, from the Iron Age through the Hellenistic Period, Vol. 1, Jerusalem 2015, pp. 115-134.

LILYQUIST, C.

2012 Treasures from Tell Basta: Goddesses, Officials and Artists in International Age: The Metropolitan Museum Journal 47 (2012), pp. 9-72.

MATTHäUS, $\mathrm{H}$.

1985 H. MūLler-KARPE (hrsg.), Metallgefäße und Gefäßuntersätze der Bronzezeit, der geometrischen und archaischen Periode auf Cypren, Mūnchen 1985.

2001 Studies on the interrelations of Cyprus and Italy in the $11^{\text {th }}$ to $9^{\text {th }}$ centuries BC: a pan Mediterranean perspective: L. BONFANTE - V. KARAGEORGHIS (eds.), Italy and Cyprus in Antiquity 1500-450 B.C.: proceedings of an international symposium held at the Italian Academy for Advanced Studies in America at Columbia University, November 16-18, 2000, Nicosia 2001, pp. 153-214.

MAZAR, A.

2006 Excavations at Tel Beth-Shean 1989-1996. Vol. 1. From the Late Bronze Age IIB to the Medieval Period (The Israel Exploration Society, The Institute of Archaeology, The Hebrew University of Jerusalem), Jerusalem 2006.

2015 Iron Age I. Northern Coastal Plain, Galilee, Samaria, Jezreel Valley, Judah and Negev: S. Gitin (ed.), The Ancient Pottery of Israel and Its Neighbors, from the Iron Age through the Hellenistic Period, Vol. 1, Jerusalem 2015, pp. 5-70.

NEGBI, O.

1974 The continuity of the Canaanite Bronzework of the Late Bronze Age into the Early Iron Age: Tel Aviv 1/4 (1974), pp. 159-172.

1991 Were the Sea Peoples in the Central Jordan Valley at the Transition from the Bronze Age to the Iron Age?: Tel Aviv 18 (1991), pp. 205-243.

1998 Were the Sea Peoples in the Central Jordan Valley at the Transition from the Bronze Age to the Iron Age? Once Again: Tel Aviv 25 (1998), pp. 184-207. 
NigRO, L.

2014 An absolute Iron Age Chronology of the Levant and the Mediterranean: L. NigRo (ed.), Overcoming Catastrophes. Essays on disastrous agents, characterization and resilience strategies in pre-classical Southern Levant (Rome "La Sapienza" Studies on the Archaeology of Palestine \& Transjordan 11), Roma 2014, pp. 261-269.

Nigro, L. - Fiaccavento, C. - JaRAdAt, M. - Yasine, M.

2015 Archaeology from A to Z: Abu Zarad, an ancient town in the heartland of Palestine. The Italian-Palestinian Joint Archaeological Project at Tell Abu Zarad (Yasuf, Salfeet, Palestine) - First season of archaeological investigations, May-June 2015: Vicino Oriente XIX (2015), pp. 139-183.

NuÑEZ CALVO, F.J.

2008-2009 A Snapshot of the Phoenician Ceramic Sequence: The neck-ridge jug from Tell el-Ghassil at the AUB Museum: Berytus: Archaological Studies LI-LII (2008-2009), pp. 46-70.

2014 The ceramic repertoire of the Iron Age: Bulletin d'Archéologie et d'Architecture Libanaises, Hors-Série IX (2014), pp. 261-371.

2016 Considerations around a polarized Mediterranean Iron Age Chronology: L. DonNELLAN V. Nizzo - J.-B. Burgers (eds.), Contexts of Early Colonization (Papers of the Royal Netherlands Institute in Rome, Vol. 64), Roma 2016, pp. 73-88.

Papantoniou, G. - Bourogiannis, G.

2018 The Cypriot Extra-Urban Sanctuary as a Central Place: the Case of Agia Irini: Land 7(4) (2018), pp. 1-27.

PETRIE, W.M.F.

1930 Beth-Pelet I (Tell Fara), London 1930.

PRAUSNITZ, M.W.

1997 The stratigraphy and the Ceramic Typology of Early Iron Age tombs at Akhziv: Michmanim 11 (1997) (The Bulletin of the Reuben and Edith Hecht Museum), pp. 17-30.

PRITCHARD, J.B.

1975 Sarepta. A. preliminary report on the Iron Age. Excavations of the University Museum of the University of Pennsylvania, 1970-72 (Museum Monographs), Philadelphia 1975.

RADWAN, A.

1983 Die Kupfer- und Bronzegefässe Ägyptens: Von den Anfängen bis zum Beginn der Spätzeit (Prähistorische Bronzefunde II.2), Mūnchen 1983.

SPAGNOLI, F

2010 Cooking pots as an indicator of cultural relations between Levantine peoples in Late Bronze and Iron Ages. Origins, diffusion and typological development of cooking ware in Levantine and Cypriot repertoires $\left(14^{\text {th }}-7^{\text {th }}\right.$ centuries BC) (Quaderni di Archeologia Fenicio-Punica IV), Roma 2010.

STERN, E.

2015 Iron Age I-II Phoenician Pottery: S. Gitin (ed.), The Ancient Pottery of Israel and Its Neighbors, from the Iron Age through the Hellenistic Period, Vol. 1, Jerusalem 2015, pp. 435-482.

TAPPY, R.E.

2015 Iron Age IIA-B: Samaria: S. GITIN (ed.), The Ancient Pottery of Israel and Its Neighbors, TUFNELL, $\mathrm{O}$. from the Iron Age through the Hellenistic Period, Vol. 1, Jerusalem 2015, pp. 189-212.

1953 Lachish III. The Iron Age (The Wellcome-Marston Archaeological Reserch Expedition to the Near East), London - New York - Toronto 1953. 
WAMPLER, J.C.

1947 Tell en-Nasbeh. Vol. II, The pottery (The Palestine Institute of Pacific School of Religion and the American Schools of Oriental Research), Berkeley - New Haven 1947.

YEZERSKI, I.

2010 Chapter Three: Iron Age II Pottery: H. GEvA (ed.), Jewish Quarter Excavations in the Old City of Jerusalem, Conducted by Nahman Avigad 1969-1982, Vol. IV: The Burnt House of Area B, and Other Studies, Final Report, Jerusalem 2010, pp. 97-117.

YEZERSKI, I. - GEVA, H.

2003 Iron Age II Clay Figurines: H. GEVA (ed.), Jewish Quarter Excavations in the Old City of Jerusalem, Conducted by Nahman Avigad 1969-1982, Vol. II: The Finds from Areas A, W and X-2, Final Report, Jerusalem 2003, pp. 63-84.

ZuKerman, A. - Gitin, S.

2016 A Typological Analysis of the Iron Age I Ceramic Corpus from Strata VII-IV: S. GITIN (ed.), Miqne-Ekron 9/1. Field IV Lower. The Iron Age I Early Philistine City, Winona Lake (Indiana) 2016, pp. 417-440. 


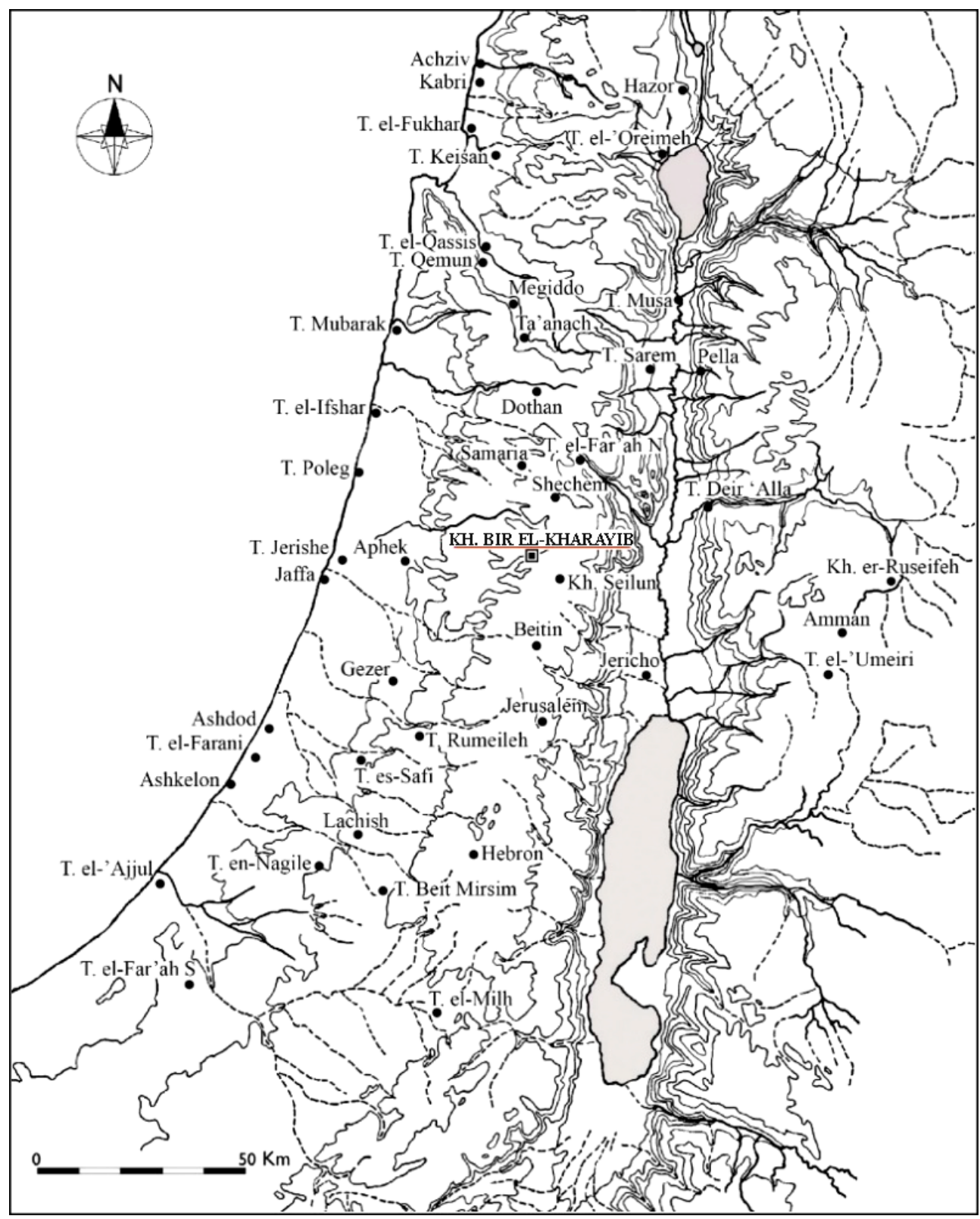

Fig. 1 - Map of Palestine with main sites of the Iron Age and Khirbet Bir el-Kharayib in the heartland of the country. 


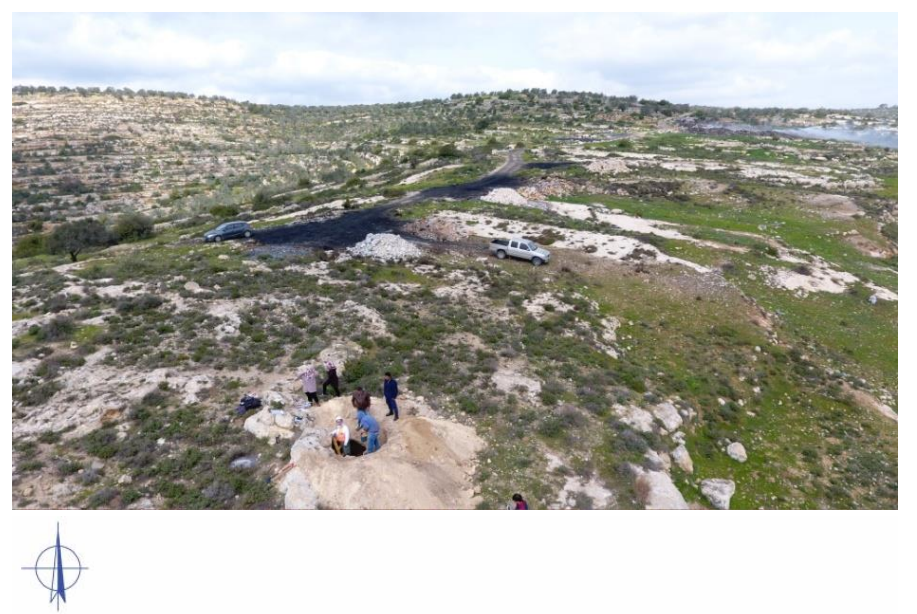

Fig. 2 - The tomb during the excavation and the surrounding area (photo by Maher Bargothi).
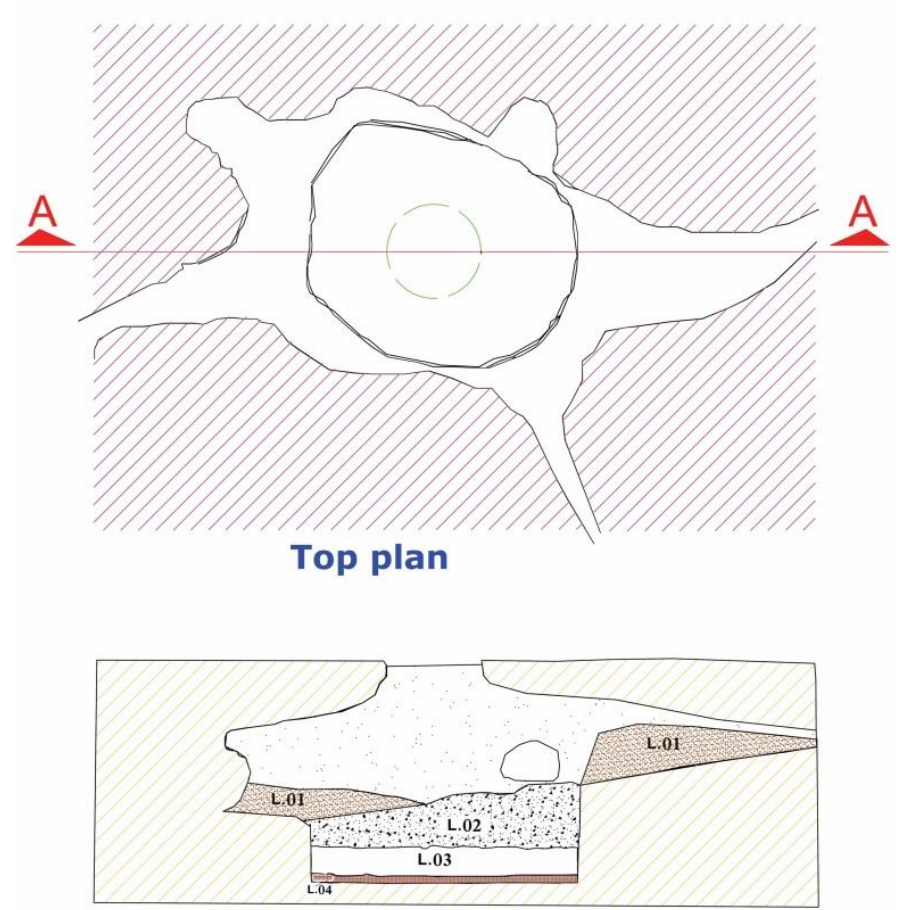

section A-A

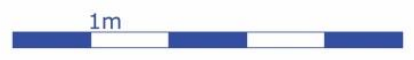

Fig. 3 - Plan and section of the tomb. 

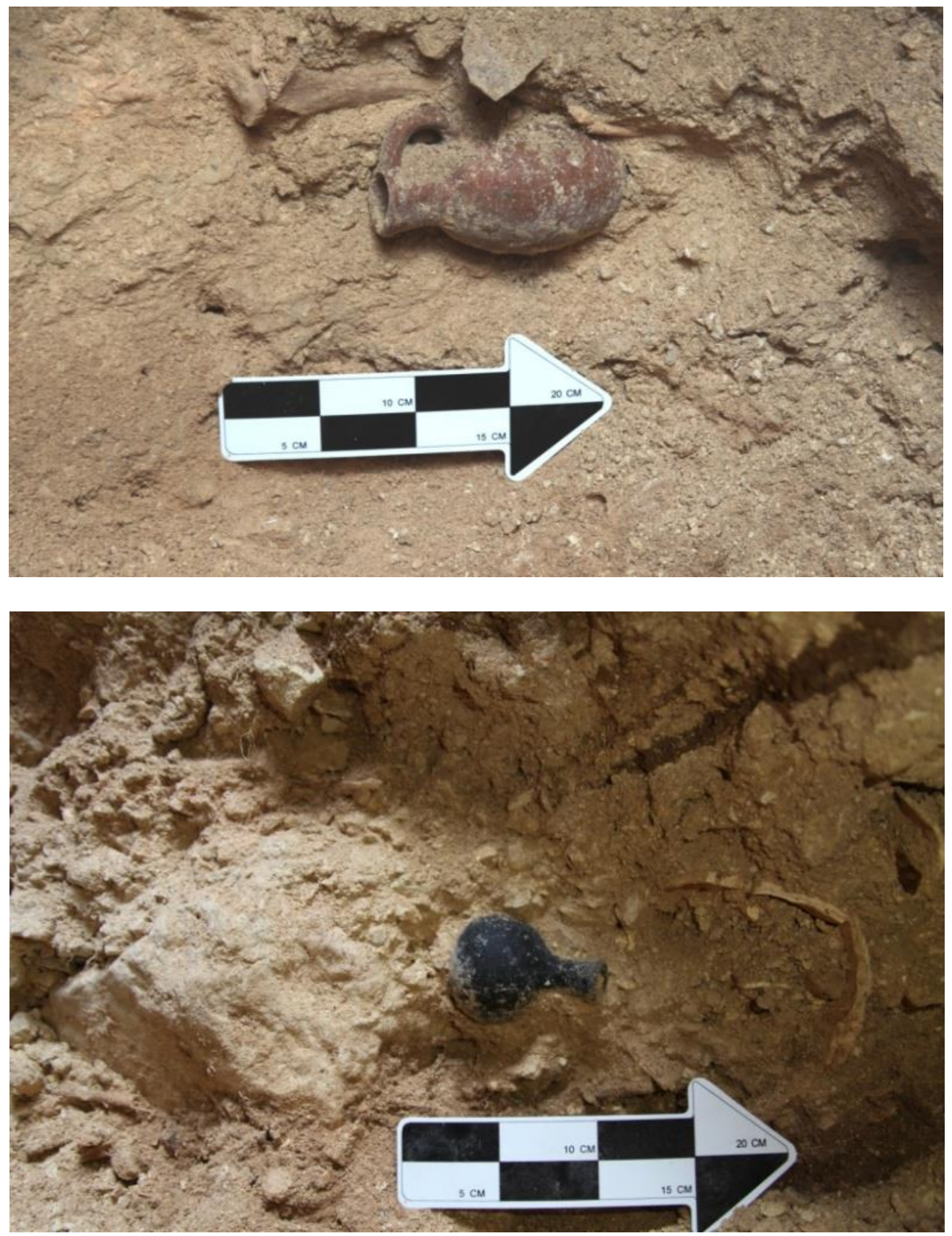

Fig. 4 - Human bones and ceramic finds photographed together during the discovery in the burial layer L.03. 

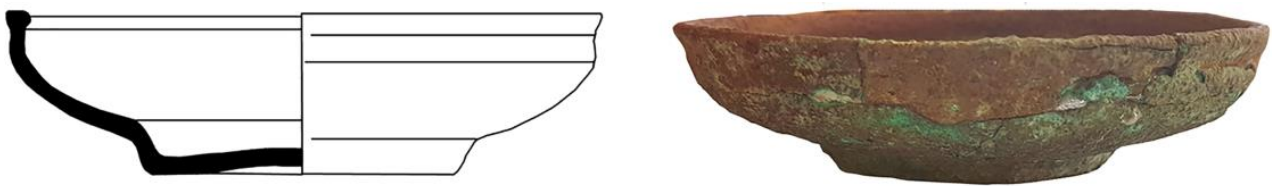

a

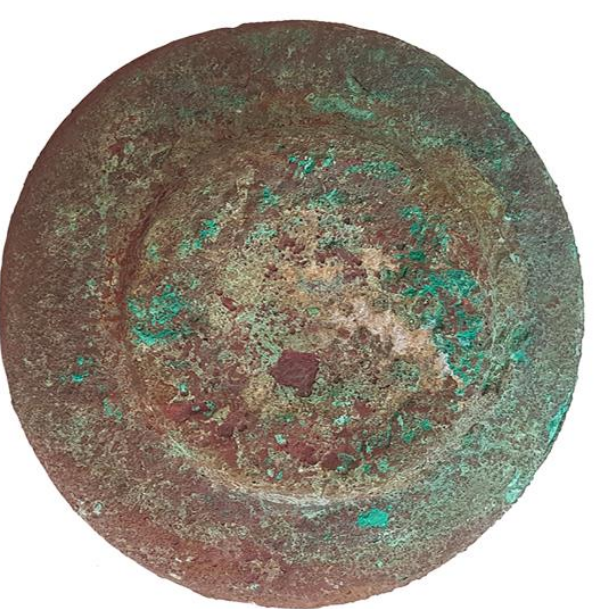

b
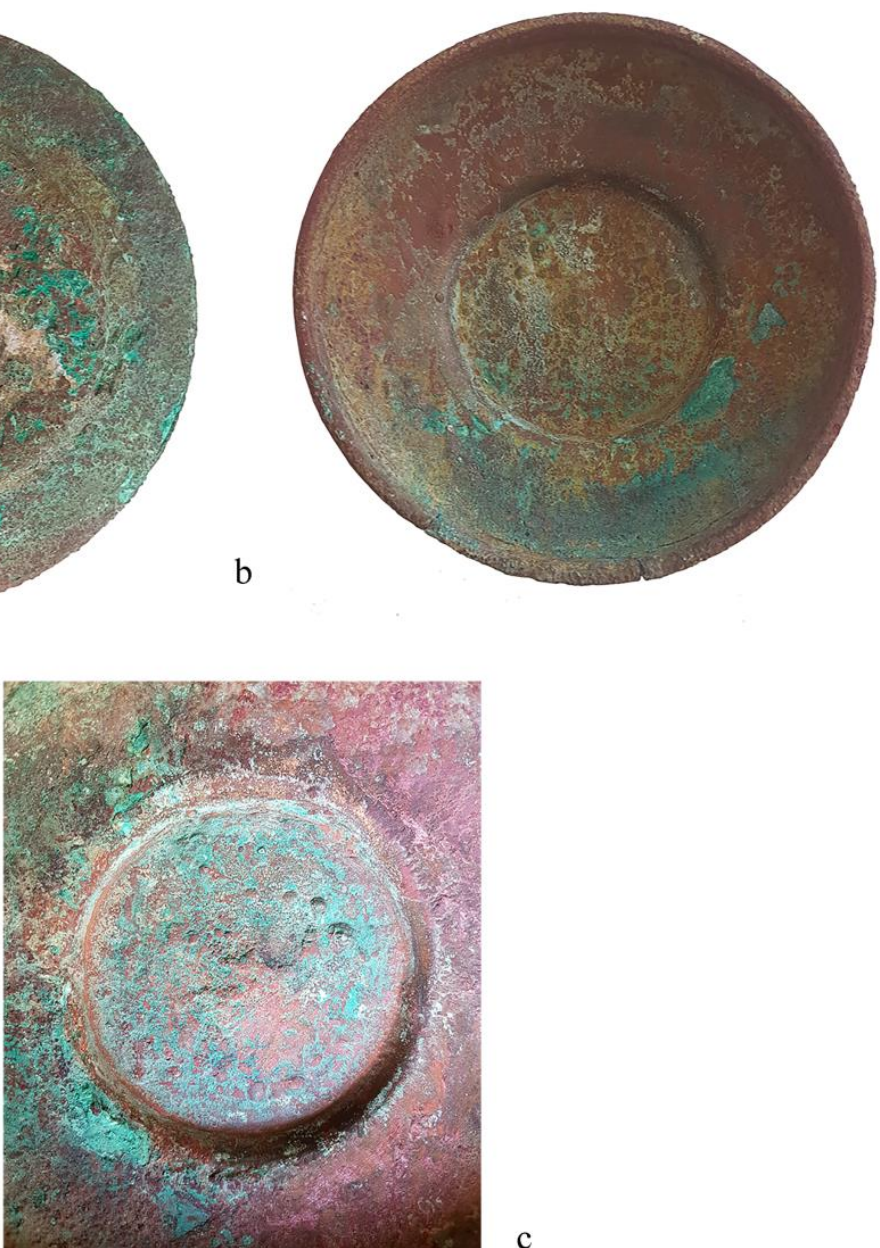

SL69

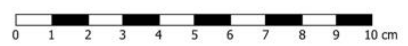

Fig. 5 - The bronze bowl SL69 with slightly convex disc base, inverted rim and low carination. 


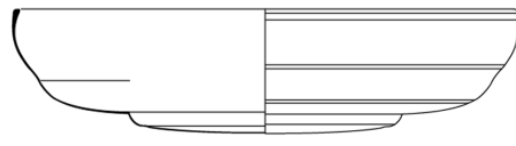

1

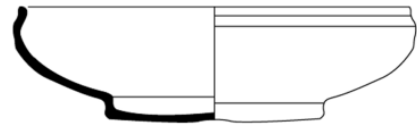

2

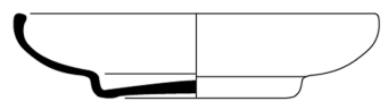

4

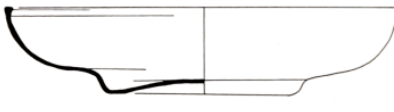

3

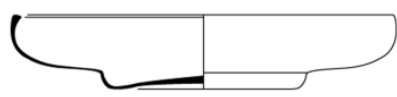

5

Fig. 6 - Late Bronze and Early Iron Ages metallic bowls from Egypt and Levant. 1. Silver bowl from Tell Basta (after Lilyquist 2012, 58, fig. 76); 2. Bronze bowl from Azor cemetery (after Ben-Shlomo 2012, 157-159, fig. 5.24.1); 3. Bronze bowl from Dothan tomb (after Gershuny 1985, pl. 4:48); 4-5. Bronze bowls from Tel Jatt grave (after Artzy 2006, 55-56, pl. 2:J-37,J-38). 

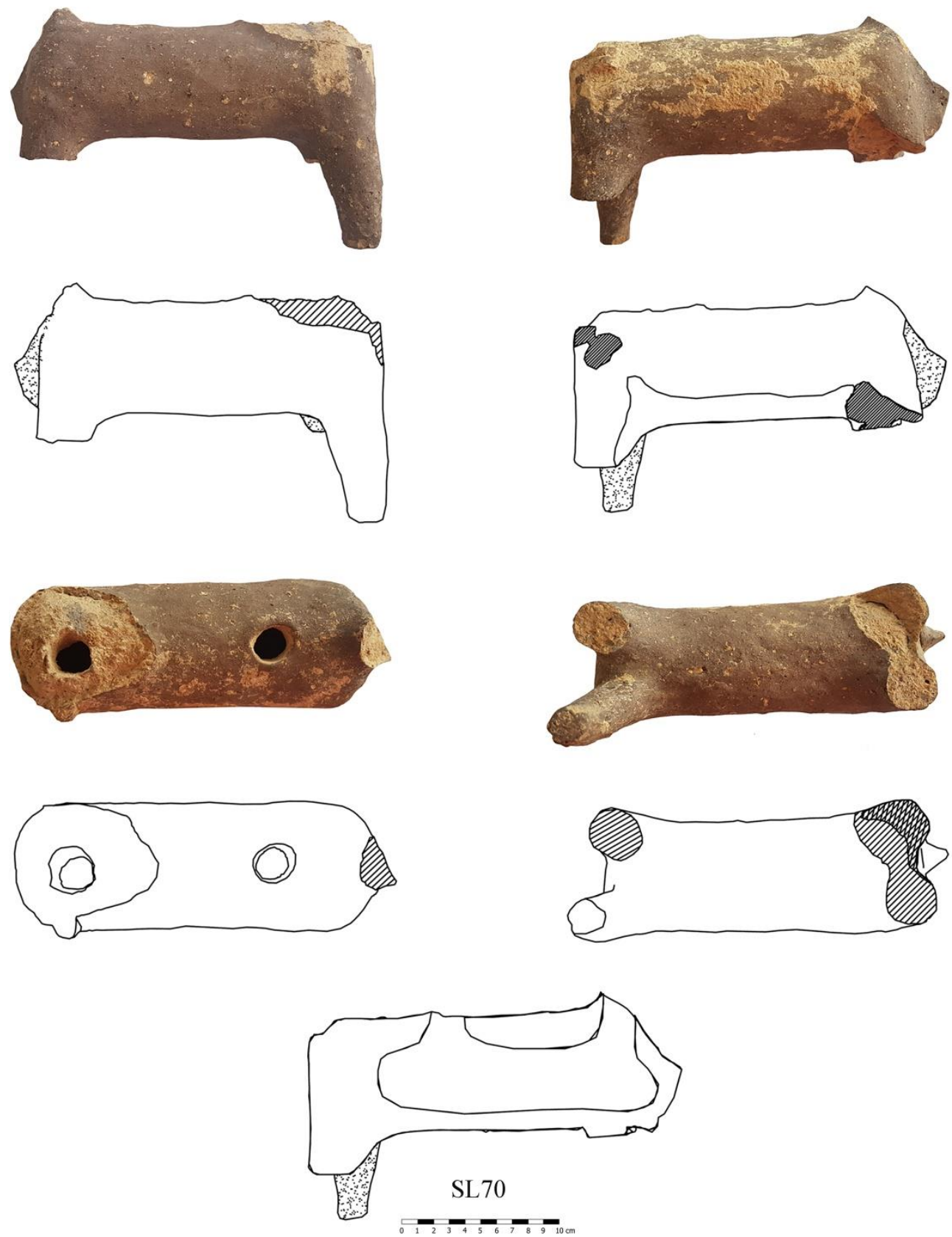

Fig. 7 - The zoomorphic figurine SL70. 

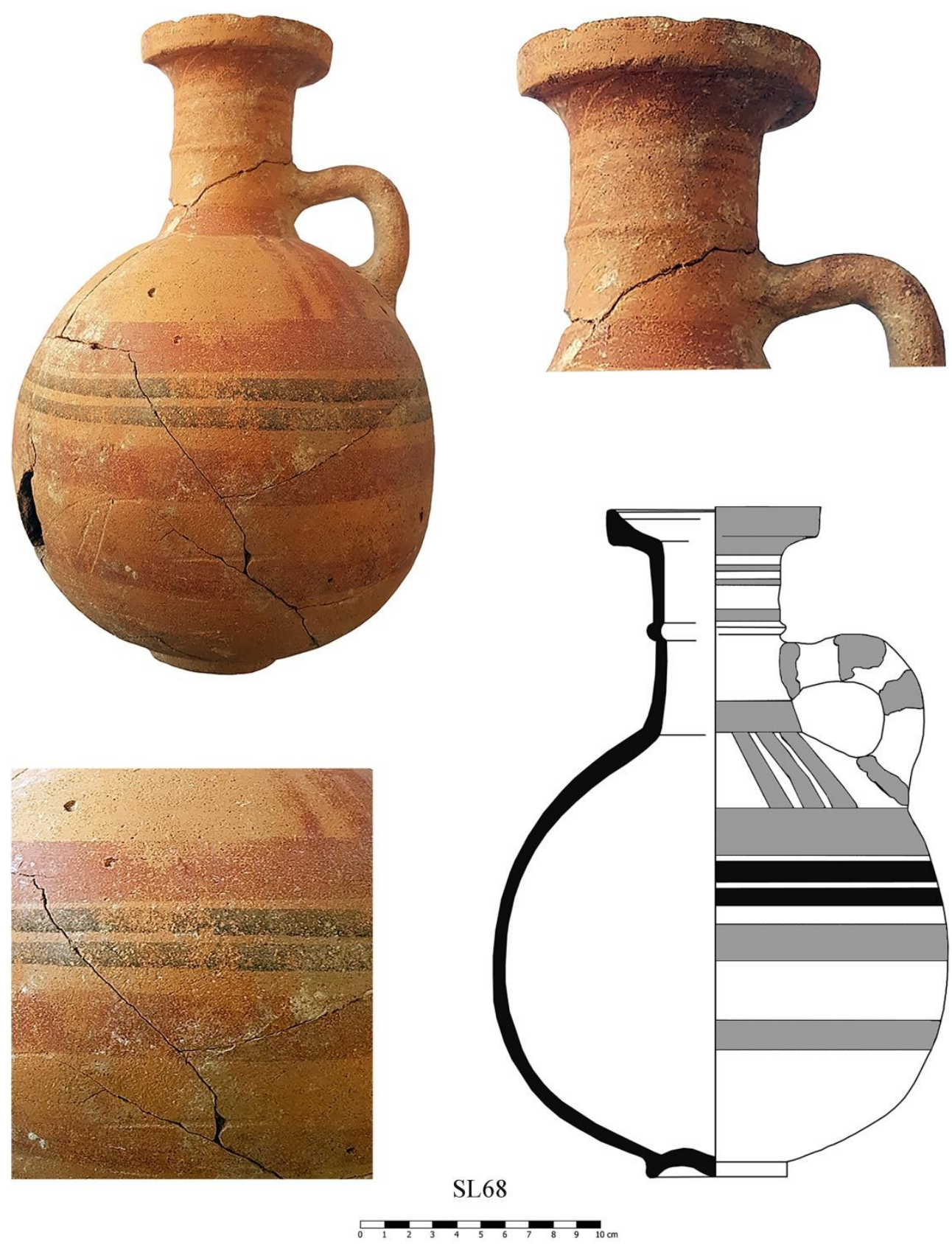

Fig. 8 -The Bichrome Ware neck-ridge jug SL68. 


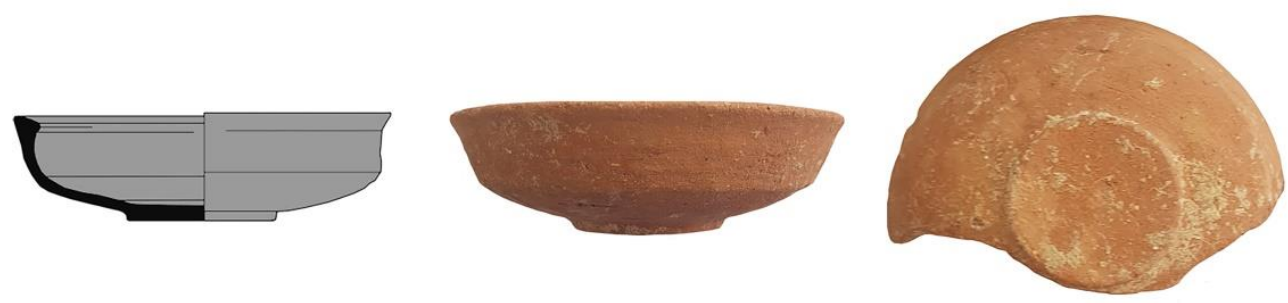

1. B2
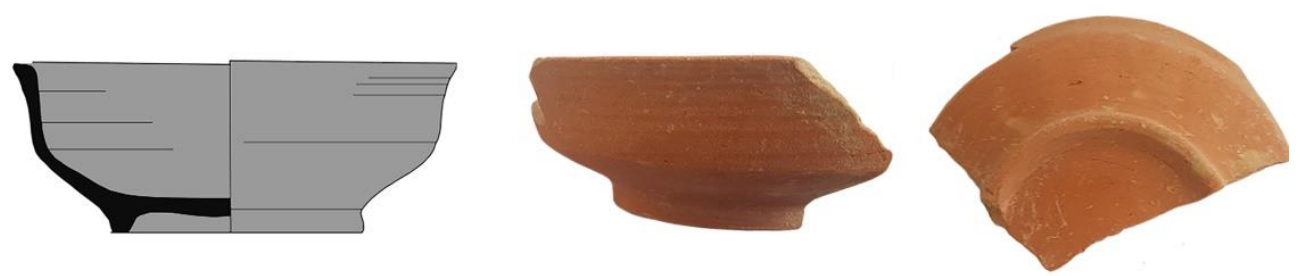

2. B1
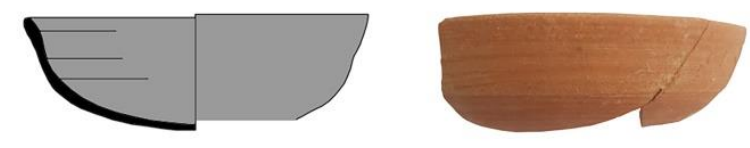

3. B3
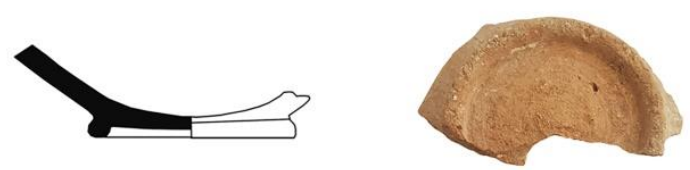

4. B4

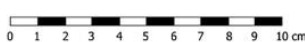

Fig. 9 - Iron Age II bowls from Khirbet Bir el-Kharayib tomb. 

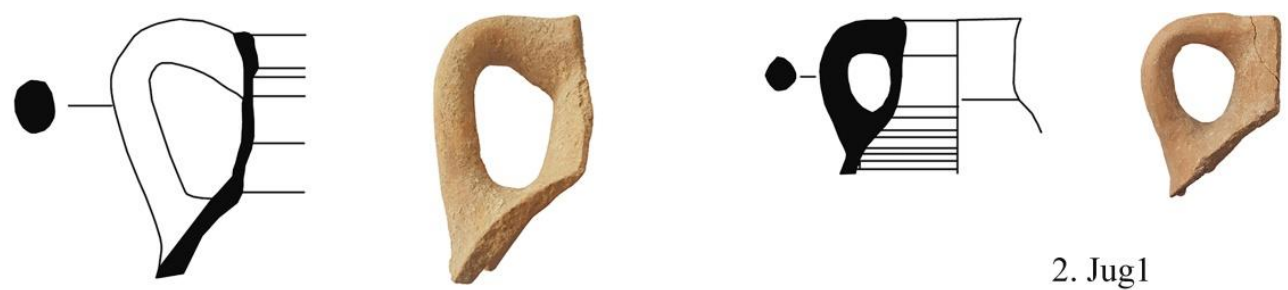

\section{Jug1}

1. Jug2
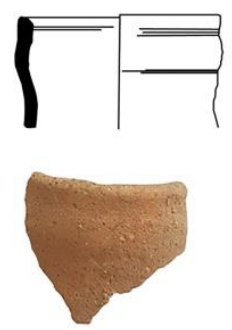

3. J3
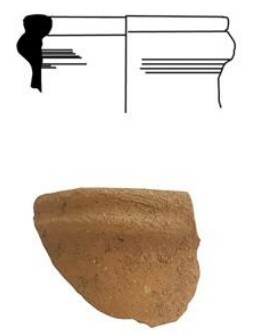

4. J1
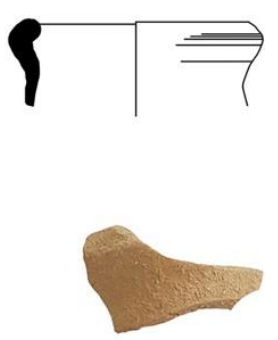

5. J2
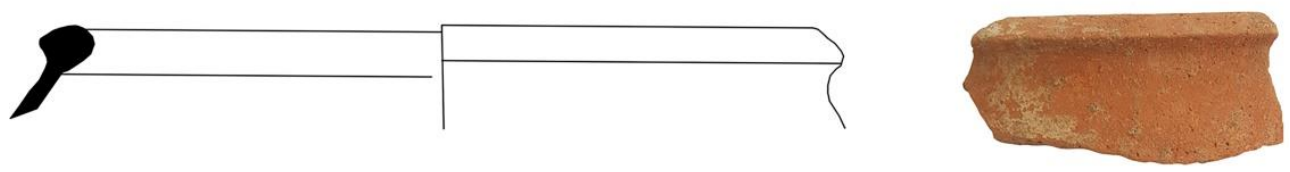

6. $\mathrm{C} 1$
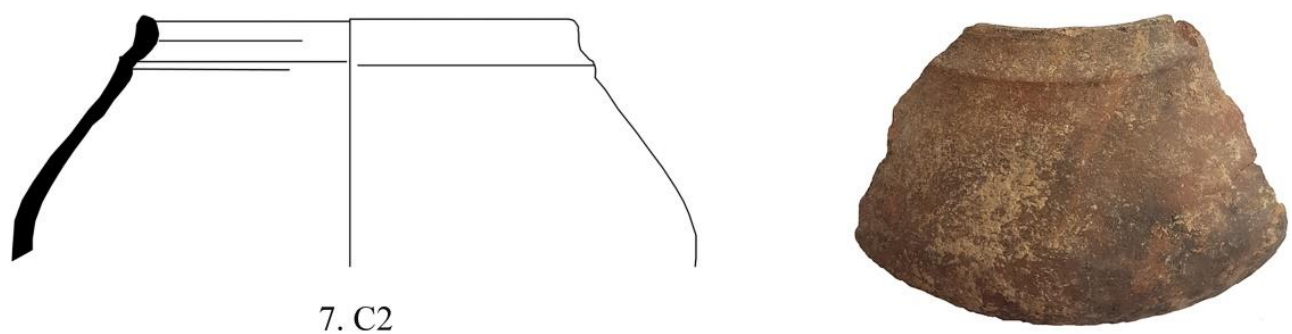

7. $\mathrm{C} 2$

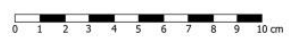

Fig. 10 - Iron Age II jugs, jars (1-5) and Cooking pots (6-7) from Khirbet Bir el-Kharayib tomb. 


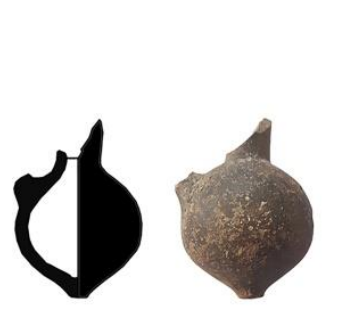

1. SL81

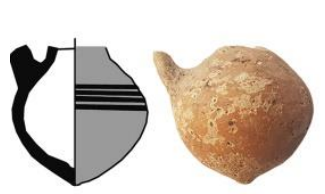

4. SL80

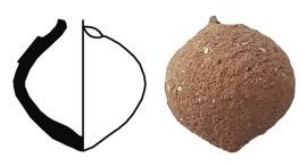

6. SL83

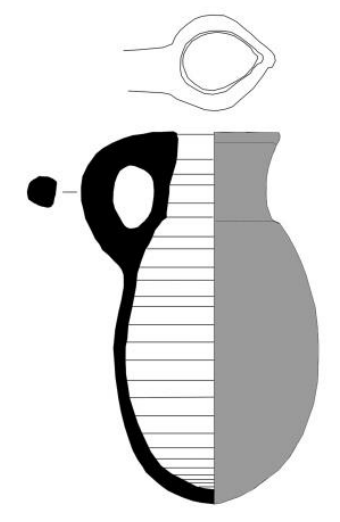

9. SL78

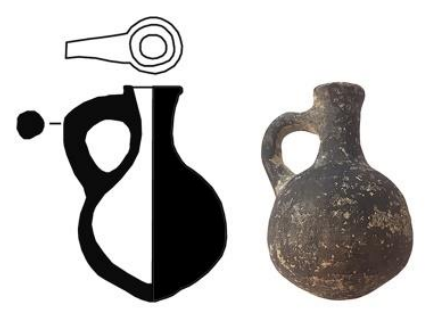

2. SL74

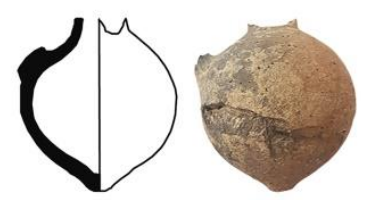

5. SL84

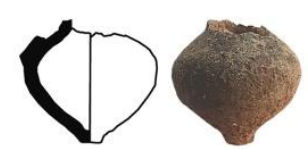

7. SL82
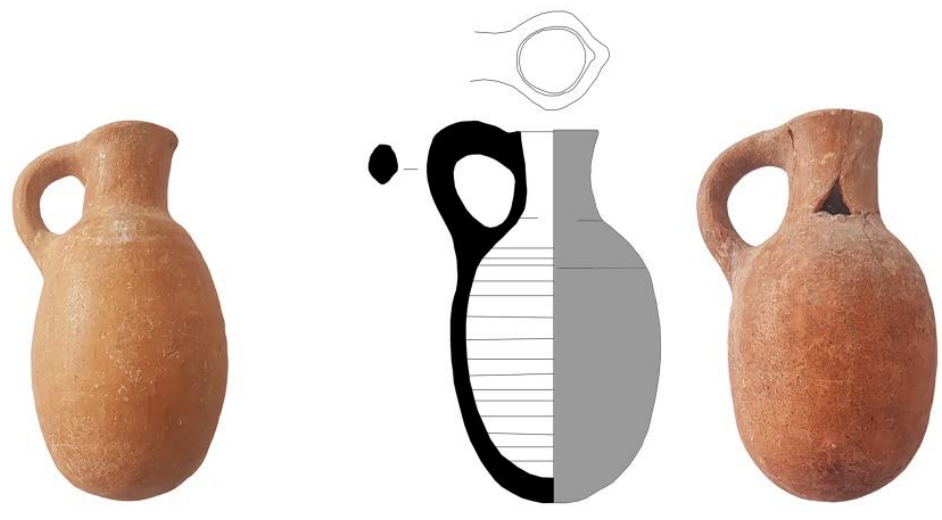

10. SL76

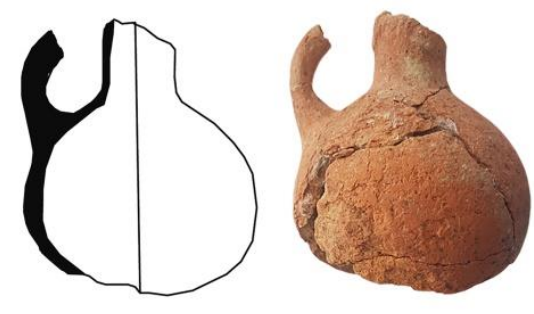

8. SL85

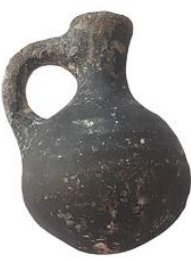

3. SL75

- $25+56-10 \mathrm{~m}$

Fig. 11 - Iron Age II Black Slip juglets (1-3), BoR juglet (4), Simple Ware juglets (5-8) and Red Slip dipper juglets (9-10) from Khirbet Bir el-Kharayib tomb. 


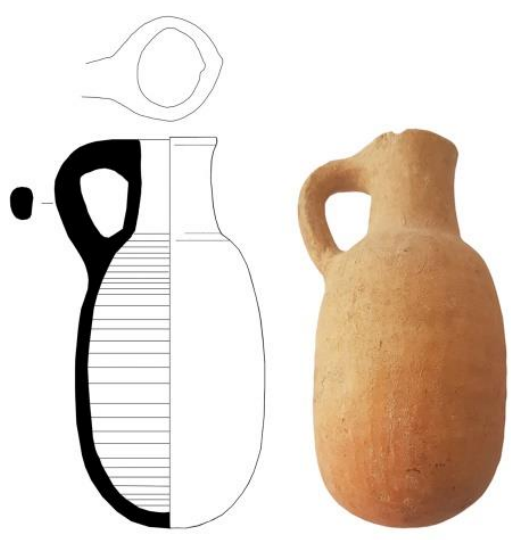

1. SL79

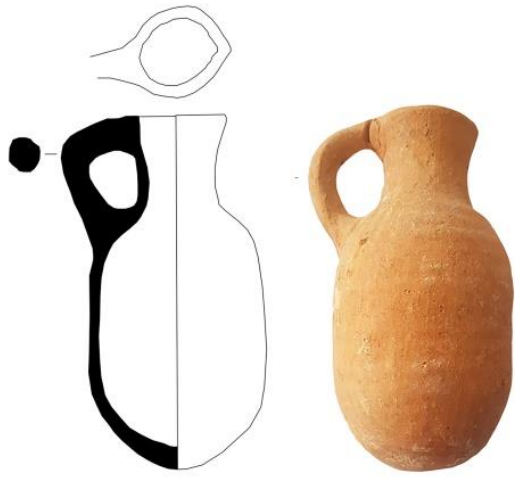

2. SL72
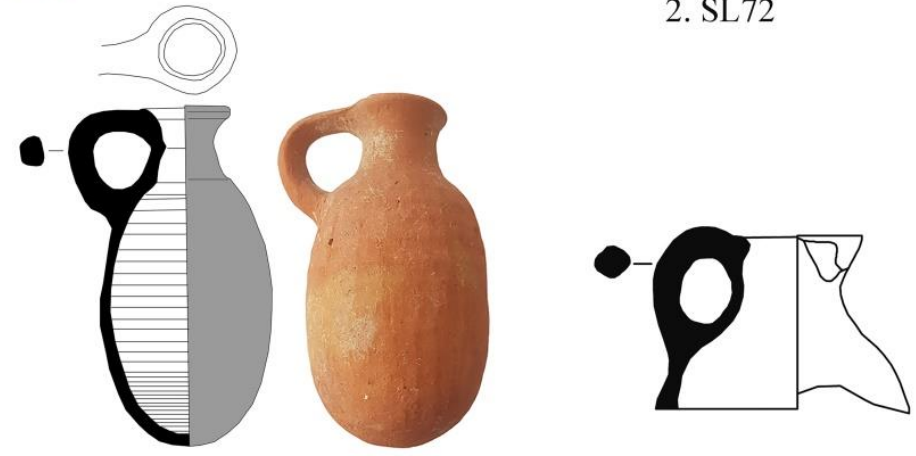

3. SL77
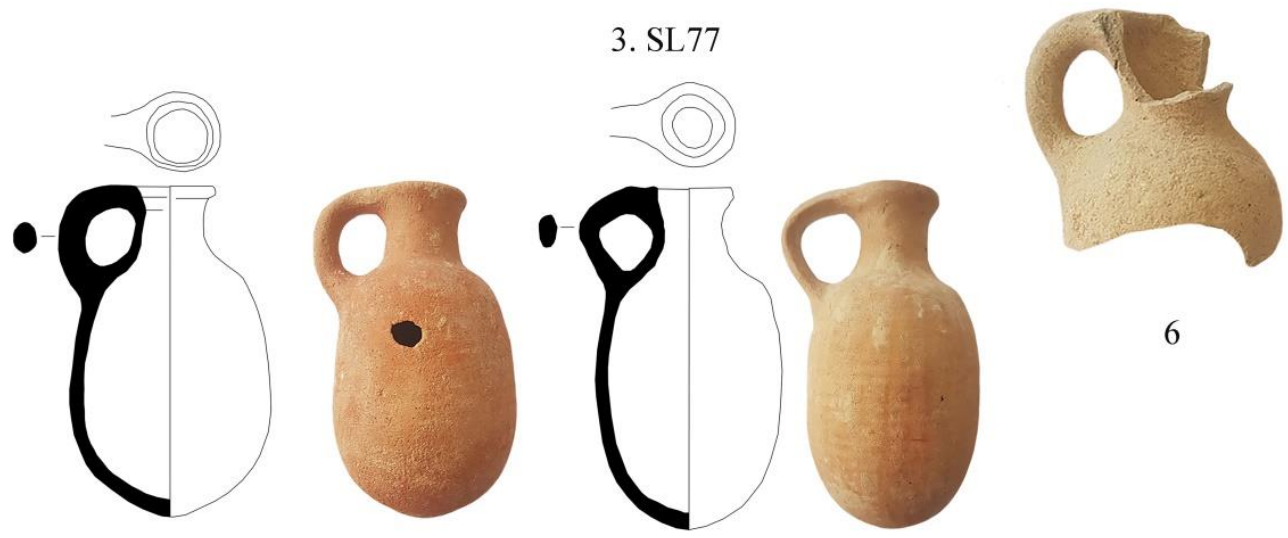

6

4. SL71

5. SL73

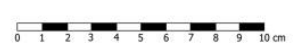

Fig. 12 - Iron Age II Red Slip and Simple Ware dipper juglets from Khirbet Bir elKharayib tomb. 


\begin{tabular}{|c|c|c|c|c|c|c|}
\hline N. & Shape/Type & Description & $\begin{array}{c}\text { Sourface } \\
\text { Treatment }\end{array}$ & Dating & Comparisons & References \\
\hline $\begin{array}{l}\text { Fig. } 5 \\
\text { SL69 }\end{array}$ & Bronze bowl & $\begin{array}{l}\text { Curved bowl with flat } \\
\text { base and inverted rim. }\end{array}$ & & IA I-IIA & Azor Tomb D63 & $\begin{array}{l}\text { Ben-Shlomo 2008a, } 46 \text {, } \\
\text { fig. } 21: 1\end{array}$ \\
\hline $\begin{array}{l}\text { Fig. } 7 \\
\text { SL70 }\end{array}$ & $\begin{array}{l}\text { Zoomorphic } \\
\text { figurine }\end{array}$ & $\begin{array}{c}\text { Missing head. } \\
\text { Cylindrical hollow } \\
\text { body, long legs and hole } \\
\text { on the back }\end{array}$ & & IA IIA & Tel Moza & $\begin{array}{l}\text { Kisilevitz 2015, 158- } \\
\text { 159, fig. } 6\end{array}$ \\
\hline $\begin{array}{l}\text { Fig. } 8 \\
\text { SL68 }\end{array}$ & $\begin{array}{l}\text { Bichrome } \\
\text { Ware } \\
\text { Jug }\end{array}$ & $\begin{array}{l}\text { Neck-ridge jug with up- } \\
\text { right tapered lip, } \\
\text { globular body and ring } \\
\text { base }\end{array}$ & & IA IIA & $\begin{array}{l}\text { Megiddo } \\
\text { VA-IVB }\end{array}$ & $\begin{array}{l}\text { Finkelstein - Zimhoni - } \\
\text { Kafri 2000, fig. 11.32:5 }\end{array}$ \\
\hline $\begin{array}{l}\text { Fig. } 9.1 \\
\text { B2 }\end{array}$ & Red Slip bowl & $\begin{array}{l}\text { Carinated bowl with } \\
\text { angled rim and disc base }\end{array}$ & - & IA IIA & Sulam IIa & $\begin{array}{c}\text { Alexandre } 2007,27 \text {, fig. } \\
2: 3\end{array}$ \\
\hline $\begin{array}{l}\text { Fig. } 9.2 \\
\text { B1 }\end{array}$ & Red Slip bowl & $\begin{array}{l}\text { Carinated bowl with } \\
\text { slightly out-turned rim } \\
\text { and wide ring base }\end{array}$ & $\begin{array}{l}\text { Irregular } \\
\text { hand- } \\
\text { burnishing }\end{array}$ & IA IIA & $\begin{array}{l}\text { Beth Shean } \\
\text { S-1a }\end{array}$ & $\begin{array}{c}\text { Mazar 2006, 404-405, } \\
\text { pl. 9:9 }\end{array}$ \\
\hline $\begin{array}{l}\text { Fig. } 9.3 \\
\text { B3 }\end{array}$ & Red Slip bowl & Hemispherical bowl & $\begin{array}{l}\text { Irregular } \\
\text { hand- } \\
\text { burnishing }\end{array}$ & IA IIA & $\begin{array}{l}\text { Horbat Rosh } \\
\text { Zayit IIa }\end{array}$ & $\begin{array}{l}\text { Gal - Alexandre 2000, } \\
\text { 108-109, fig. III.87:14 }\end{array}$ \\
\hline $\begin{array}{l}\text { Fig. } 9.4 \\
\text { B4 }\end{array}$ & $\begin{array}{l}\text { Simple Ware } \\
\text { bowl }\end{array}$ & Ring base & - & $\begin{array}{l}\text { IA IIA- } \\
\text { B }\end{array}$ & - & - \\
\hline $\begin{array}{l}\text { Fig. } 10.1 \\
\text { Jug2 }\end{array}$ & $\begin{array}{l}\text { Simple Ware } \\
\text { jug }\end{array}$ & $\begin{array}{l}\text { Jug with simple rim, } \\
\text { cylindrical neck and } \\
\text { single handle }\end{array}$ & - & $\begin{array}{l}\text { IA IIA- } \\
\mathrm{B}\end{array}$ & $\begin{array}{l}\text { Tell el Far'ah } \\
\text { North VIIb }\end{array}$ & $\begin{array}{l}\text { Tappy } 2015,206-208, \\
\text { pl. } 2.3 .9: 3\end{array}$ \\
\hline $\begin{array}{l}\text { Fig. } 10.2 \\
\text { Jug1 }\end{array}$ & $\begin{array}{l}\text { Simple Ware } \\
\text { jug }\end{array}$ & $\begin{array}{l}\text { Jug with simple rim, } \\
\text { cylindrical neck and } \\
\text { single handle }\end{array}$ & $\begin{array}{c}\text { Vertical } \\
\text { hand- } \\
\text { burnishing }\end{array}$ & $\begin{array}{l}\text { IA IIA- } \\
\text { B }\end{array}$ & $\begin{array}{l}\text { Horbat Rosh } \\
\text { Zayit I }\end{array}$ & $\begin{array}{l}\text { Gal - Alexandre 2000, } \\
\text { 144-145, fig. III.122:14 }\end{array}$ \\
\hline $\begin{array}{l}\text { Fig. } 10.3 \\
\text { J3 }\end{array}$ & $\begin{array}{l}\text { Simple Ware } \\
\text { jar or jug }\end{array}$ & $\begin{array}{l}\text { Simple rim, narrow } \\
\text { vertical neck and slight } \\
\text { ridge }\end{array}$ & - & IA IIA & $\begin{array}{l}\text { Beth Shean } \\
\text { S-1a }\end{array}$ & $\begin{array}{c}\text { Mazar 2006, 406-407, } \\
\text { pl. 10:5 }\end{array}$ \\
\hline $\begin{array}{l}\text { Fig. } 10.4 \\
\text { J1 }\end{array}$ & $\begin{array}{l}\text { Simple Ware } \\
\text { jar or jug }\end{array}$ & Ridged bow rim & - & $\begin{array}{l}\text { IA IIA- } \\
\mathrm{B}\end{array}$ & $\begin{array}{l}\text { Megiddo } \\
\text { VA-IVB }\end{array}$ & $\begin{array}{c}\text { Finkelstein - Zimhoni - } \\
\text { Kafri 2000, 299, fig. } \\
11.41: 4 \\
\end{array}$ \\
\hline $\begin{array}{l}\text { Fig. } 10.5 \\
\text { J2 }\end{array}$ & $\begin{array}{l}\text { Simple Ware } \\
\text { jar or jug }\end{array}$ & Bow rim & - & IA IIA & $\begin{array}{l}\text { Rasm el-Arusm } \\
\text { Tomb }\end{array}$ & $\begin{array}{l}\text { Abadi-Reiss 2016, fig. } \\
14: 5\end{array}$ \\
\hline $\begin{array}{l}\text { Fig. } 10.6 \\
\text { C1 }\end{array}$ & Cooking pot & $\begin{array}{l}\text { Pot with inclined upper } \\
\text { sidewall and a short } \\
\text { triangular-shaped rim } \\
\end{array}$ & - & $\begin{array}{l}\text { IA IIA- } \\
\text { B }\end{array}$ & Samaria VI & $\begin{array}{c}\text { Tappy } 2015,202-203 \text {, } \\
\text { pl. } 2.3 .5: 2\end{array}$ \\
\hline $\begin{array}{l}\text { Fig. } 10.7 \\
\quad \text { C2 }\end{array}$ & Cooking pot & $\begin{array}{l}\text { Squatted pot with } \\
\text { rounded low carination } \\
\text { and simple rim with a } \\
\text { slight ridge below }\end{array}$ & - & $\begin{array}{l}\text { IA IIA- } \\
\text { B }\end{array}$ & Megiddo H-3 & $\begin{array}{l}\text { Finkelstein - Zimhoni - } \\
\text { Kafri 2000, 303-304, } \\
\text { fig. 11.41:6 }\end{array}$ \\
\hline $\begin{array}{l}\text { Fig. } 11.1 \\
\text { SL81 }\end{array}$ & $\begin{array}{c}\text { Black } \\
\text { Slip Juglet }\end{array}$ & $\begin{array}{l}\text { Globular juglet with } \\
\text { high cylindrical neck } \\
\text { and bottom base }\end{array}$ & $\begin{array}{c}\text { Vertical } \\
\text { burnishing }\end{array}$ & IA IIA & $\begin{array}{l}\text { Lachish } \\
\text { Tomb } 521\end{array}$ & Tufnell 1953, pl. 88:328 \\
\hline $\begin{array}{l}\text { Fig. } 11.2 \\
\text { SL74 }\end{array}$ & $\begin{array}{c}\text { Black } \\
\text { Slip Juglet }\end{array}$ & $\begin{array}{c}\text { Globular juglet with } \\
\text { simple rim, flared neck } \\
\text { and rounded base }\end{array}$ & $\begin{array}{c}\text { Vertical } \\
\text { burnishing }\end{array}$ & $\begin{array}{l}\text { IA IIA- } \\
\text { B }\end{array}$ & $\begin{array}{l}\text { Horbat Rosh } \\
\text { Zayit IIa }\end{array}$ & $\begin{array}{l}\text { Gal - Alexandre 2000, } \\
\text { 105-106, fig. III.85:11 }\end{array}$ \\
\hline $\begin{array}{l}\text { Fig. } 11.3 \\
\text { SL75 }\end{array}$ & $\begin{array}{c}\text { Black } \\
\text { Slip Juglet }\end{array}$ & $\begin{array}{l}\text { Globular juglet with } \\
\text { inverted rim, flared neck } \\
\text { and rounded base }\end{array}$ & $\begin{array}{l}\text { Vertical } \\
\text { burnishing }\end{array}$ & $\begin{array}{l}\text { IA IIA- } \\
\text { B }\end{array}$ & Beer Sheba VI & $\begin{array}{c}\text { Herzog } 1984,60-61 \text {, fig. } \\
30: 5\end{array}$ \\
\hline $\begin{array}{l}\text { Fig. } 11.4 \\
\text { SL80 }\end{array}$ & $\begin{array}{l}\text { Black-on-Red } \\
\text { Juglet }\end{array}$ & $\begin{array}{l}\text { Red Slip globular juglet } \\
\text { with bottom base. Four } \\
\text { black painted lines on } \\
\text { the body }\end{array}$ & Polishing & IA IIA & $\begin{array}{l}\text { Megiddo } \\
\text { VB }\end{array}$ & $\begin{array}{c}\text { Finkelstein - Zimhoni - } \\
\text { Kafri 2000, 280-281, } \\
\text { fig. } 11.27: 8\end{array}$ \\
\hline $\begin{array}{l}\text { Fig. } 11.5 \\
\text { SL84 }\end{array}$ & $\begin{array}{l}\text { Simple Ware } \\
\text { juglet }\end{array}$ & $\begin{array}{l}\text { Globular juglet with } \\
\text { bottom base }\end{array}$ & - & IA IIA & $\begin{array}{l}\text { Megiddo } \\
\text { VA-IVB }\end{array}$ & $\begin{array}{c}\text { Finkelstein - Zimhoni - } \\
\text { Kafri 2000, 296-297, } \\
\text { fig. 11.39:2 }\end{array}$ \\
\hline
\end{tabular}




\begin{tabular}{|c|c|c|c|c|c|c|}
\hline N. & Shape/Type & Description & $\begin{array}{c}\text { Sourface } \\
\text { Treatment }\end{array}$ & Dating & Comparisons & References \\
\hline $\begin{array}{l}\text { Fig. } 11.6 \\
\text { SL83 }\end{array}$ & $\begin{array}{l}\text { Simple Ware } \\
\text { juglet }\end{array}$ & $\begin{array}{l}\text { Globular juglet with } \\
\text { bottom base }\end{array}$ & - & IA IIA & $\begin{array}{c}\text { Horbat Rosh } \\
\text { Zayit IIa }\end{array}$ & $\begin{array}{c}\text { Gal - Alexandre 2000, } \\
\text { 96-97, fig. III.80:14 }\end{array}$ \\
\hline $\begin{array}{l}\text { Fig. } 11.7 \\
\text { SL82 }\end{array}$ & $\begin{array}{c}\text { Simple Ware } \\
\text { juglet }\end{array}$ & $\begin{array}{l}\text { Fusiform juglet with } \\
\text { bottom base }\end{array}$ & - & IA IIA & $\begin{array}{c}\text { Horbat Rosh } \\
\text { Zayit IIa }\end{array}$ & $\begin{array}{c}\text { Gal - Alexandre 2000, } \\
\text { 96-97, fig. III.80:14 }\end{array}$ \\
\hline $\begin{array}{l}\text { Fig. } 11.8 \\
\text { SL85 }\end{array}$ & $\begin{array}{c}\text { Simple Ware } \\
\text { juglet }\end{array}$ & $\begin{array}{l}\text { Globular juglet with } \\
\text { bottom base }\end{array}$ & - & IA IIA & $\begin{array}{c}\text { Horbat Rosh } \\
\text { Zayit IIa }\end{array}$ & $\begin{array}{c}\text { Gal - Alexandre 2000, } \\
\text { 96-97, fig. III.80:14 }\end{array}$ \\
\hline $\begin{array}{l}\text { Fig. } 11.9 \\
\text { SL78 }\end{array}$ & $\begin{array}{c}\text { Red Slip } \\
\text { dipper-juglet }\end{array}$ & $\begin{array}{c}\text { Dipper juglet with high } \\
\text { flared neck, simple rim } \\
\text { and slight carinated } \\
\text { shoulder }\end{array}$ & $\begin{array}{l}\text { Vertical } \\
\text { burnishing }\end{array}$ & $\begin{array}{l}\text { IA IIA- } \\
\text { B }\end{array}$ & Beth Shean IV & $\begin{array}{c}\text { James 1966, 282-283, } \\
\text { fig. } 70: 16\end{array}$ \\
\hline $\begin{array}{l}\text { Fig. } \\
11.10 \\
\text { SL76 } \\
\end{array}$ & $\begin{array}{c}\text { Red Slip } \\
\text { dipper-juglet }\end{array}$ & $\begin{array}{c}\text { Dipper juglet with high } \\
\text { flared neck, simple rim } \\
\text { and oval body }\end{array}$ & Polishing & IA IIA & Beth Shean V & $\begin{array}{c}\text { James } 1966,272-273, \\
\text { fig. } 65: 3\end{array}$ \\
\hline $\begin{array}{l}\text { Fig. } 12.1 \\
\text { SL79 }\end{array}$ & $\begin{array}{c}\text { Simple Ware } \\
\text { juglet }\end{array}$ & $\begin{array}{l}\text { Dipper juglet with high } \\
\text { flared neck, simple rim } \\
\text { and oval body }\end{array}$ & $\begin{array}{c}\text { Vertical } \\
\text { burnishing }\end{array}$ & IA IIA & $\begin{array}{c}\text { Rasm el-Arusm } \\
\text { Tomb }\end{array}$ & $\begin{array}{c}\text { Abadi-Reiss 2016, fig. } \\
\text { 14:1 }\end{array}$ \\
\hline $\begin{array}{l}\text { Fig. } 12.2 \\
\text { SL72 }\end{array}$ & $\begin{array}{l}\text { Simple Ware } \\
\text { dipper-juglet }\end{array}$ & $\begin{array}{c}\text { Dipper juglet with high } \\
\text { flared neck, simple rim } \\
\text { and slight carinated } \\
\text { shoulder }\end{array}$ & $\begin{array}{c}\text { Vertical } \\
\text { burnishing }\end{array}$ & IA IIA & $\begin{array}{c}\text { Rasm el-Arusm } \\
\text { Tomb }\end{array}$ & $\begin{array}{c}\text { Abadi-Reiss 2016, fig. } \\
14: 2\end{array}$ \\
\hline $\begin{array}{l}\text { Fig. } 12.3 \\
\text { SL77 }\end{array}$ & $\begin{array}{c}\text { Red Slip } \\
\text { dipper-juglet }\end{array}$ & $\begin{array}{c}\text { Dipper juglet with } \\
\text { narrow flared neck, } \\
\text { simple rim and oval } \\
\text { body }\end{array}$ & $\begin{array}{c}\text { Vertical } \\
\text { burnishing }\end{array}$ & $\begin{array}{l}\text { IA IIA- } \\
\text { B }\end{array}$ & Megiddo H-3 & $\begin{array}{c}\text { Finkelstein - Zimhoni - } \\
\text { Kafri } 2000,313-315, \\
\text { fig. } 11.53: 2\end{array}$ \\
\hline $\begin{array}{l}\text { Fig. } 12.4 \\
\text { SL71 }\end{array}$ & $\begin{array}{l}\text { Simple Ware } \\
\text { dipper-juglet }\end{array}$ & $\begin{array}{l}\text { Dipper juglet with } \\
\text { narrow flared neck, } \\
\text { simple rim and slight } \\
\text { carinated shoulder }\end{array}$ & - & $\begin{array}{l}\text { IA IIA- } \\
\text { B }\end{array}$ & $\begin{array}{l}\text { Horbat Rosh } \\
\text { Zayit I }\end{array}$ & $\begin{array}{l}\text { Gal - Alexandre 2000, } \\
\text { 144-145, fig. III.122:16 }\end{array}$ \\
\hline $\begin{array}{l}\text { Fig. } 12.5 \\
\text { SL73 }\end{array}$ & $\begin{array}{l}\text { Simple Ware } \\
\text { dipper-juglet }\end{array}$ & $\begin{array}{c}\text { Dipper juglet with } \\
\text { narrow flared neck, } \\
\text { inverted rim and slight } \\
\text { carinated shoulder }\end{array}$ & $\begin{array}{c}\text { Vertical } \\
\text { burnishing }\end{array}$ & $\begin{array}{l}\text { IA IIA- } \\
\text { B }\end{array}$ & $\begin{array}{c}\text { Horbat Rosh } \\
\text { Zayit IIa }\end{array}$ & $\begin{array}{c}\text { Gal - Alexandre 2000, } \\
\text { 107-108, fig. III.86:6 }\end{array}$ \\
\hline Fig. 12.6 & $\begin{array}{l}\text { Simple Ware } \\
\text { dipper-juglet }\end{array}$ & $\begin{array}{l}\text { Dipper juglet with flared } \\
\text { neck and inverted rim }\end{array}$ & - & $\begin{array}{l}\text { IA IIA- } \\
\text { B }\end{array}$ & $\begin{array}{c}\text { Horbat Rosh } \\
\text { Zayit IIa }\end{array}$ & $\begin{array}{c}\text { Gal - Alexandre 2000, } \\
\text { 107-108, fig. III.86:6 }\end{array}$ \\
\hline
\end{tabular}

Tab. 1 - List of the Iron Age II funerary goods of the tomb at Khirbet Bir el-Kharayib. 